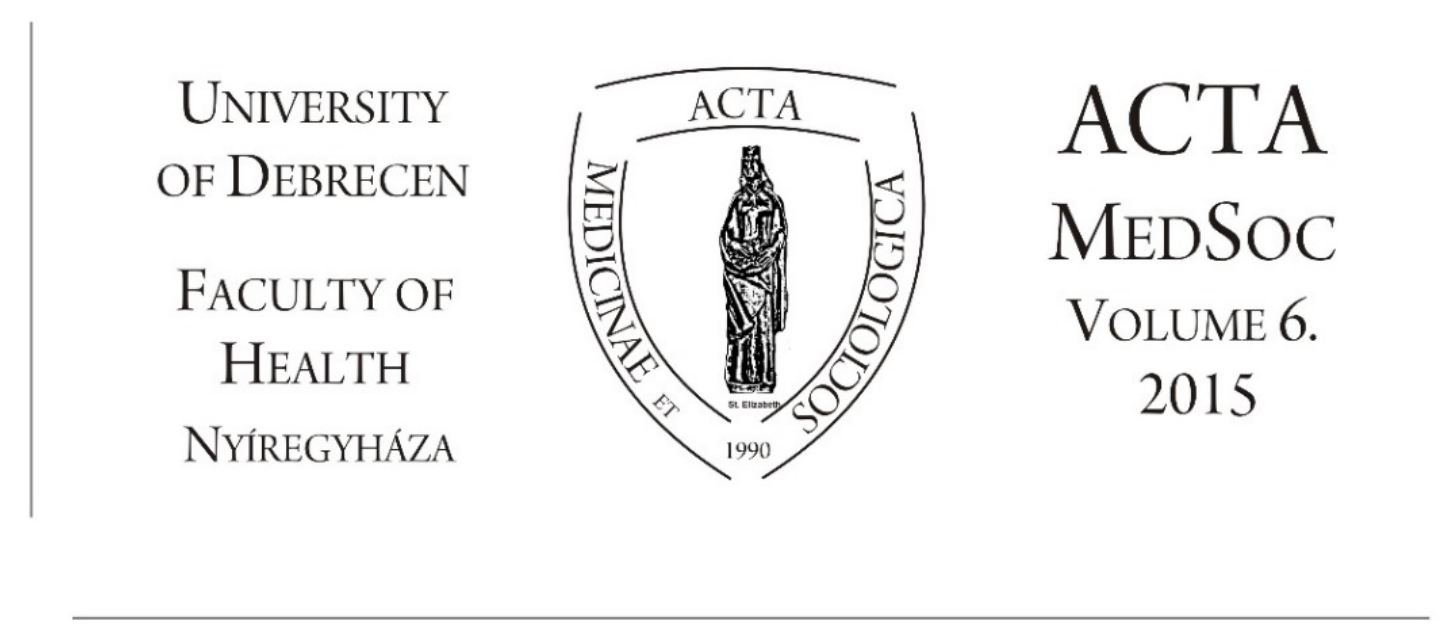

\title{
A foglalkoztatás és a munkanélküliség jellemzői a Nyíregyházi járásban
}

\author{
R. Fedor Anita - Balogh Erzsébet
}

\begin{abstract}
This research examines the employment characteristics of Nyíregyháza and the municipalities of the Nyíregyháza district. Previous research (collected every second year from 2008 -2015) related to this topic offers the possibility to compare data from the county seat where trends in employment can be measured. Features of the district are also compared to the Nyíregyháza data. The study examines the changes in employment and unemployment related to the level of education. A comparison of national and county public employment that includes educational levels provides a new and different analysis.

Overall it can be concluded there was a slight decline in the employment level during this period for the inhabitants of Nyíregyháza. Based upon the data it might be explained (compared to the earlier years) by a higher rate of women retiring that was made possible by legislative changes.

Results reveal changes in the composition of the economic activity of the respondents. This finding is similar to those found in the EU, national, regional, town and district relations where employment was correlated with educational level. For levels the higher the educational level the higher the level of employment. However, research focusing on public employment the opposite with respect to educational levels and is the same as the national findings. The higher the educational level the lower the rate of public employment. Those who have the lowest educational level have the greatest percent of people employed in the public sector.
\end{abstract}

Keywords: employment rate, unemployment rate, school education, regional context 


\section{Bevezetés}

A fizetett munka meghatározó szerepet tölt be az egyének, családok életében, s annak elvesztése nehézségek sorozata elé állíthatja az érintetteket. A munka nélkül eltöltött idö hosszának emelkedése pedig tovább ronthatja a munkajövedelem hiányát megtapasztaló háztartások életkörülményeit. A modern társadalomban a munka az önbecsülés fontos eleme, mely a munkát végző számára biztosítja a megélhetéshez szükséges anyagi forrást, melynek hiányában az egyén napi megélhetési gondjai megsokszorozódhatnak. A munkahely barátokat, társas kapcsolatokat is jelent, és lehetőséget biztosít közös tevékenységekben való részvételre. (Giddens, 1995) A munkavégzés és az abból származó jövedelem nagymértékben hozzájárul az egyének és családok életminőségéhez, alakíthatja az önminősített szubjektív egészségi állapotról alkotott véleményeket. (Jávorné Erdei, R. Fedor, Berencsiné, 2014; Jávorné Erdei et. al, 2014)

Tanulmányunkban nem vállaljuk a fent említett összefüggések mindegyikének feltérképezését. Egyrészt terjedelmi korlátok miatt, másrészt a tanulmánykötet szerzői közül Huszti Éva írása részletesen foglalkozik a társas kapcsolatok elemzésével, míg Fábián Gergely, Takács Péter és Szigeti Fruzsina munkája a jövedelmi viszonyok alakulását járja körbe. Mindezeket figyelembe véve elemző munkánkban Nyíregyháza város, valamint a Nyíregyházi járás településeinek foglalkoztatási jellemzőit vizsgáljuk. Elemző munkánkban bemutatunk egy-egy, a tanulmány tartalmi kereteivel harmonizáló hazai (országos) és európai uniós összefüggést is. Ezzel az a célunk, hogy az olvasó a helyi jellemzők mellett bepillantást nyerjen a legáltalánosabb, globális foglalkoztatási helyzetben bekövetkező változásokba. A témához kapcsolódó kutatási előzmények lehetőséget adnak arra, hogy a megyeszékhely vonatkozó adatait 2008-tól kezdődően (kétévenként) egészen 2015-ig összehasonlítsuk, mely segítségével rávilágíthatunk a foglalkoztatásban bekövezett változásokra. A járási jellemzőket a nyíregyházi adatok kontextusában vizsgáljuk. Kitérünk a foglalkoztatás, valamint a munkanélküliség iskolai végzettség szerinti alakulására. Új elemként jelenik meg a közfoglalkoztatottak vizsgálata, melyet országos, megyei viszonyban mutatunk be. A közfoglalkoztatottak iskolai végzettség függvényében való vizsgálatunk a városra és a járásra terjed ki.

\section{Általános helyzetkép}

Magyarország foglalkoztatási helyzete a 2009-as helyzethez képest folyamatos javulást mutat, a foglalkoztatottak számában történő növekedés 2009 és 2014 között 352500 fó volt. A foglalkoztatottak száma nemcsak elérte, de meg is haladta a 2008ban elkezdődött, hazánkat 2009-re elérő gazdasági válság elötti mutatót. A 15-64 éves korú népességre vonatkoztatott foglalkozatási ráta 2014-ben 61,8\% volt, 5,1\%kal magasabb, mint 2012-ben, és közel 7\%-kal kedvezőbb a 2010-es állapothoz képest (KSH 2.1.2)

A legfrissebb (2014) adatok szerint az Európai Unióban átlagosan 69,2\% volt a 20 és 64 év közötti korosztály foglalkoztatási rátája. Nemzetközi viszonylatban igen kedvezötlen Görögország (53,3\%), valamint Spanyolország $(59,9 \%)$ helyzete, s a 
korábbi adatoknak megfelelően kiemelkedik a sorból Svédország (80\%), Hollandia (80\%) és Dánia (80\%) foglalkoztatási rátája. Magyarország helyzete, a maga 66,7\%os mutatójával alig marad le az Európai Unió átlagától. Ezt egyértelműen kedvező változásként értékelhetjük, hiszen a 2010. évi adatok szerint a hazai foglalkoztatási arány $(57,2 \%)$ pontosan 7\%-kal volt kevesebb, mint az EU-27 átlaga $(64,2 \%)$ (Eurostat, http://appsso.eurostat.ec.europa.eu/nui/show.do). Hazánk a 75\%-os foglalkoztatási ráta elérést tűzte ki célul 2020-ra. Bár látható, hogy a 2014-es mutató és az elérendő cél közötti különbség 8,3\%, de az éves adatok alapján elmondható, hogy hazánk most áll a legközelebb e célként megjelölt foglalkoztatási szint eléréséhez.

1. sz. ábra: A foglalkoztatottság aránya $(\%)^{16,17}$

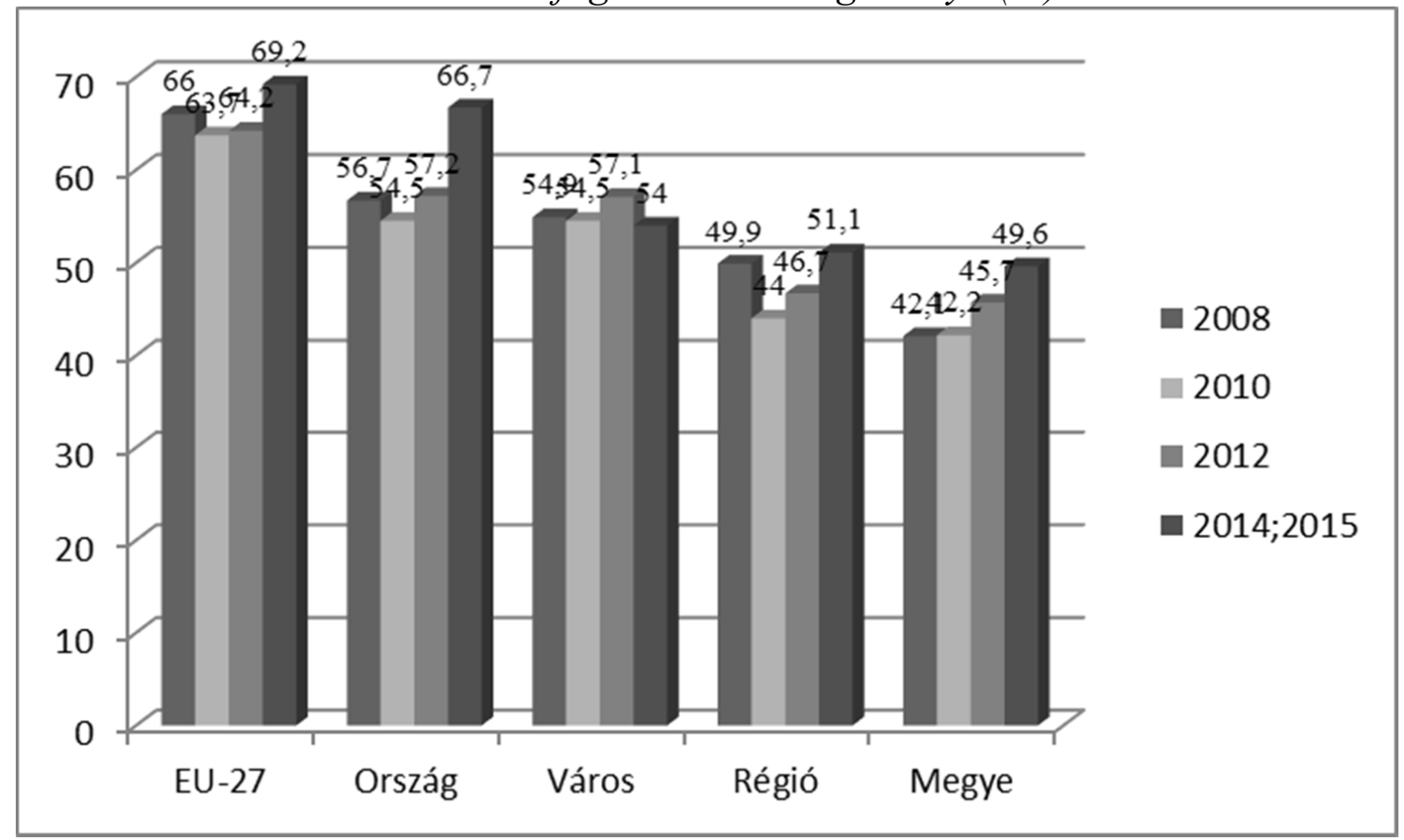

Forrás: Eurostat, http://appsso.eurostat.ec.europa.eu/nui/show.do, KSH, https://www.ksh.hu/docs/hun/xstadat/xstadat_eves/i_qlf016.html,, Nyíregyháza Életminösége 2008, 2010, 2012, 2015

Az 1. számú diagram adatai alapján látható, hogy a foglalkoztatottak számában 2012-től érzékelhető javuló tendencia mind az Európai Unió, mind az ország, a régió és a megye vonatkozásában is tovább folytatódott, azzal a különbséggel, hogy a kedvező változás még inkább hangsúlyosabb, mint a két évvel korábbi. A nyíregyházi tendencia ettől eltérően alakult, a fizetett munkát végzők arányában csökkenés figyelhető meg (az okokkal írásunkban részletesen foglalkozunk).

${ }^{16}$ Kutatásunk módszertanilag különbözik a KSH által végzett munkaerő felméréstől. Ott a 15-74, illetve 15-64 év közötti korosztályokra vetítve mérik a foglalkoztatottságot, a nyíregyházi kutatás mintájába pedig eleve a 18 éves és annál idősebbek kerülhettek be. Az Európai uniós és az országos adatok a 20-64 év közötti korosztályra vonatkoznak.

${ }^{17}$ Az utolsóként megjelenő városi oszlop a 2015-ben felvett kérdőívek adatát tartalmazza. 
Az Észak-alföldi régió foglalkoztatási rátája folyamatosan alatta marad az országosan mért átlaghoz képest. Ennek magyarázata, hogy a régióhoz tartozó Szabolcs-Szatmár-Bereg megye egyike a foglalkoztatási nehézségekkel leginkább küzdő megyéknek. Jelenleg az Észak-magyarországi az egyetlen olyan régió (48,7\%), ahol alacsonyabb a foglalkoztatottak aránya, a Dél-dunántúli (51\%) és a Dél-alföldi (52\%) régió helyzete pedig közel egybeesik az Észak-Alföldön mért adatokkal. Hazánk kiemelkedő munkaerő-piaci helyzetü régióihoz tartozik KözépMagyarország, Közép-Dunántúl és Nyugat-Dunántúl. A regionális foglalkoztatási helyzet javulása azonban kétségtelen, hiszen 2010 és 2014 között több mint 6\%-kal nőtt a foglalkoztatási ráta. (KSH stadat 6.2.1.10)

1. sz. táblázat: Foglalkoztatási arány (2008-2014) [\%]

\begin{tabular}{||llllllll||}
\hline & $\mathbf{2 0 0 8}$ & $\mathbf{2 0 0 9}$ & $\mathbf{2 0 1 0}$ & $\mathbf{2 0 1 1}$ & $\mathbf{2 0 1 2}$ & $\mathbf{2 0 1 3}$ & $\mathbf{2 0 1 4}$ \\
\hline Hajdú-Bihar & 44,8 & 42,7 & 43,9 & 45,8 & 46,0 & 47,5 & 50,3 \\
Jász-Nagykun-Szolnok & 48,6 & 46,6 & 46,5 & 46,9 & 48,3 & 48,9 & 54,2 \\
Szabolcs-Szatmár-Bereg & 40,9 & 40,8 & 42,0 & 42,1 & 45,3 & 46,5 & 49,6 \\
Észak-Alföld & $\mathbf{4 4 , 3}$ & $\mathbf{4 3 , 0}$ & $\mathbf{4 3 , 9}$ & $\mathbf{4 4 , 7}$ & $\mathbf{4 6 , 3}$ & $\mathbf{4 7 , 5}$ & $\mathbf{5 1 , 1}$ \\
Országos & $\mathbf{5 0 , 0}$ & $\mathbf{4 8 , 8}$ & $\mathbf{4 8 , 7}$ & $\mathbf{4 9 , 1}$ & $\mathbf{5 0 , 1}$ & $\mathbf{5 1 , 2}$ & $\mathbf{5 4 , 1}$ \\
\hline
\end{tabular}

Forrás:KSH stadat 6.2.1.10

https://www.ksh.hu/docs/hun/xstadat/xstadat_eves/i_qlf026b.html

A munkanélküliségi mutatókban szintén javuló tendencia figyelhető meg mind az országos, mind pedig a regionális adatokat tekintve, azonban az Észak-alföldi régió hátrányos munkaerő-piaci helyhelyzete továbbra is tetten érhető. A régióhoz tartozó megyék közül Szabolcs-Szatmár-Bereg megye sereghajtó, míg a Jász-NagykunSzolnok megyei adatok folyamatosan a legjobbak. A legfrissebb adatok szerint az említett megyék közötti különbség 6\%, Jász-Nagykun-Szolnok megye javára. GyőrMoson-Sopron (3\%), Vas (3,6\%) és Komárom-Esztergom (4,3\%) megye munkanélküliségi mutatói pedig szinte már eltörpülnek a legrosszabb helyzetü megyék mellett (KSH satadat 6.2.1.11.)

2. sz. táblázat: Munkanélküliségi ráta (2008-2014) [\%]

\begin{tabular}{|c|c|c|c|c|c|c|c|}
\hline & 2008 & 2009 & 2010 & 2011 & 2012 & 2013 & 2014 \\
\hline Hajdú-Bihar & 9,3 & 11,7 & 13,2 & 13,4 & 13,3 & 14,9 & 12,5 \\
\hline Jász-Nagykun-Szolnok & 8,5 & 11,3 & 10,7 & 11,3 & 11,5 & 11,3 & 7,6 \\
\hline Szabolcs-Szatmár-Bereg & 17,6 & 18,5 & 18,1 & 18,2 & 16,3 & 15,7 & 13,6 \\
\hline Észak-Alföld & 12,1 & 14,1 & 14,4 & 14,6 & 13,9 & 14,2 & 11,8 \\
\hline Országos & 7,8 & 10,0 & 11,2 & 11,0 & 11,0 & 10,2 & 7,7 \\
\hline
\end{tabular}

https://www.ksh.hu/docs/hun/xstadat/xstadat_eves/i_qlf027b.html

A Nyíregyházi járás vizsgálatában részvevők 52\%-a válaszolt igennel arra a kérdésre, hogy „Dolgozik-e Ön jelenleg”. Az egyes járáshoz tartozó települések 
értékei között azonban jelentős eltérések tapasztalhatók. Nyírturán 65\%, Kálmánházán 68\%, Nyírpazonyban 71\% a megkérdezés pillanatában dolgozók aránya. Nyírtura és Nyírpazony kiemelkedő mutatói a megyeszékhely közelségéből adódó nagyvárosi jellemzőkkel magyarázható, ezek a települések mind gazdasági, mind pedig foglalkoztatási szempontból közelítenek a nyíregyházi adottságokhoz. (Malkucziné, 2015) E tekintetben a középmezőnyt erősíti Nyíregyháza 54\%-kal, Apagy 56\%-kal, Nyírtelek 68\%-kal, míg Napkor, Rakamaz, Timár és Újfehértó adatai arról árulkodnak, hogy ezeken a településeken többen vannak azok, akik jelenleg nem dolgoznak. Az okok magyarázata részben gazdasági, részben pedig demográfiai jellemzőkre vezethető vissza. A megkérdezés a nyári mezőgazdasági szüretelési, betakarítási munkálatok megkezdésével egy időbe esett, így az átlagnál kedvezőbb települések egyrészt a mezőgazdasági adottságoknak, másrészt a városiasabb jellegnek ,köszönhetik eredményeiket”. Rakamaz, mint a turisztikai központnak számító Tokaj vonzáskörzetéhez tartozó település alacsony foglalkoztatási részesedése (33\%) nehezen magyarázható. Vélhetően - hasonlóan a többi foglalkoztatási szempontból kedvezőtlen helyzetü településekhez - a szükös álláslehetőségek mellett a helyi lakosság korösszetételében keresendő a magyarázat. A nyíregyházi lakosok foglalkoztatásában némi változás figyelhető meg, kissé visszaesett a megkérdezés időpontjában dolgozók aránya a 2012-ben tapasztaltakhoz képest $(57,1 \%)$, és szinte egybeesett a 2008-as szinttel (54,5\%).

3. sz. táblázat: „Dolgozik-e Ön jelenleg” (2015) [\%]

\begin{tabular}{||lcll||}
\hline & Igen & Nem & Összesen \\
\hline Nyíregyháza & 54,2 & 45,8 & 100,0 \\
Apagy & 56,4 & 43,6 & 100,0 \\
Kálmánháza & 34,0 & 32,0 & 100,0 \\
Kótaj & 43,0 & 52,2 & 100,0 \\
Nagycserkesz & 46,4 & 53,6 & 100,0 \\
Napkor & 38,7 & 61,3 & 100,0 \\
Nyírpazony & 70,8 & 29,2 & 100,0 \\
Nyírtelek & 50,0 & 50,0 & 100,0 \\
Nyírtura & 65,0 & 35,0 & 100,0 \\
Rakamaz & 35,9 & 64,1 & 100,0 \\
Timár & 40,7 & 59,3 & 100,0 \\
Újfehértó & 45,7 & 54,3 & 100,0 \\
Összesen & $\mathbf{5 1 , 6}$ & $\mathbf{4 8 , 4}$ & $\mathbf{1 0 0 , 0}$ \\
\hline
\end{tabular}

Forrás: Nyíregyháza Életminősége 2015.

A megkérdezettek 44\%-a volt már munkanélküli eddigi élete során, de mindössze csak 8,1\% nyilatkozott úgy, hogy jelenleg is munkanélküli. Ez igen kedvezőnek tekinthető mindannak tudatában, hogy mind az Észak-alföldi régió (11,8\%), mind pedig Szabolcs-Szatmár-Bereg megye (13,6\%) 2014-es munkanélküliségi mutatója 
jóval magasabb ehhez viszonyítva. Az átlagos járási mutató alig magasabb, mint az országos átlag (7,7\%). (KSH stadat 6.2.1.11.) A nyíregyházi lakosok valamivel több mint egyharmada tapasztalta már meg a munkanélküliség tényét, azonban mindössze 5,7\%-uk nyilatkozott úgy, hogy jelenleg is munkanélküli. A járás további településeit vizsgálva ezek a jellemzők már kevésbé kedvezőek. A válaszadók több mint fele(!) volt már munkanélküli eddigi élete során, $10 \%$-uk jelenleg is elhelyezkedési nehézséggel küzd. A járás települései közül Napkor (20\%), Kótaj (13\%), Nyírtura $(13,9 \%)$ helyzete mutatkozik a legrosszabbnak. Látható tehát, hogy Nyíregyháza, mint a kistérség (és a megye) központja nagyságából, fejlettségéből, megyeszékhely jellegéből adódóan több és jobb elhelyezkedési lehetőséget kínál a kistérség és egyben a megye lakói számára is.

2. sz. ábra: A munkanélküliség alakulás $(2014,2015)$ [\%]

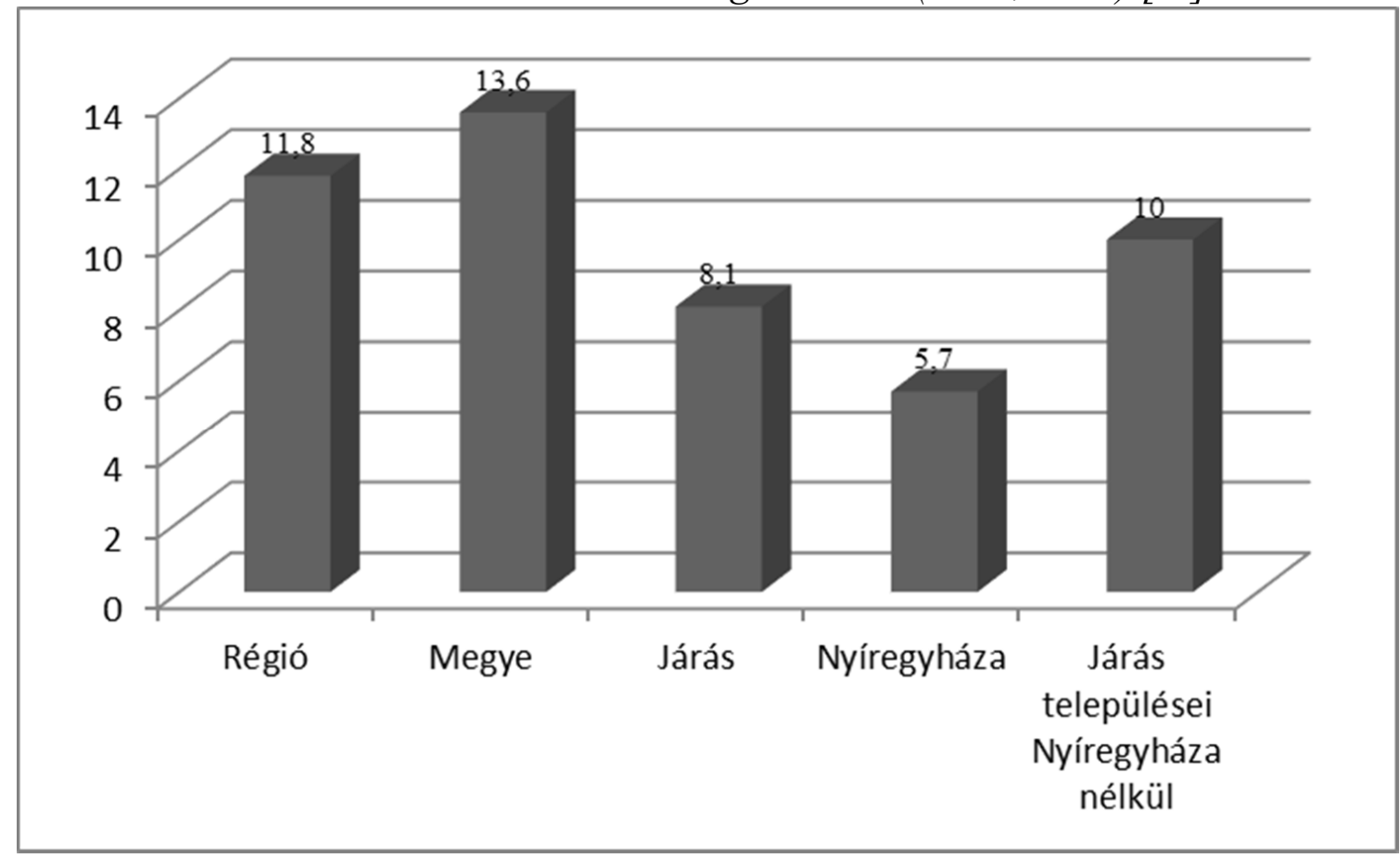

Forrás: KSH satadat 6.2.1.11,

https://www.ksh.hu/docs/hun/xstadat/xstadat_eves/i_qlf027b.html Nyirregyháza Életminösége 2015.

A munkavégzés típusát tekintve azt tapasztaltuk, hogy a válaszadók 18,6\%-a, mint önálló, vállalkozó dolgozik, 4\%, pedig vezető beosztású alkalmazott. Az alkalmazásban állók egyharmada az alkalmazott szellemi, míg közel háromnegyede az alkalmazott fizikai kategóriához sorolta magát.

A járásban élő fizetett munkát végzőkre alapvetően a teljes idejü foglalkoztatás a jellemző, a megkérdezettek mindössze 9,5\%-a dolgozik heti 40 óránál kevesebbet. A csökkentett munkaidejü foglalkoztatottak között a legnagyobb számban azok vannak, akiknek eredetileg is heti 40 óránál kevesebb időtartamra szól a szerződése, de az okok között megjelenik a gyermekgondozással-, neveléssel kapcsolatos teendők, valamint az egészségi állapot megváltozása is. 
A munkaerö-piaci érvényesülés több tényezőtől függ; említhetjük itt többek között a legmagasabb iskolai végzettséget (tanulmányunk második részében ezzel részletesen foglalkozunk), a munkaerő-piaci tapasztalatot, a településtípust, stb. Azonban a kapcsolati tőke fontosságát sem hanyagolhatjuk el, már csak azért sem, mert az informális információforrás, valamint az álláskeresési technikák ismerete segítséget jelenthet tájékozódni megüresedett, vagy újonnan létrejött potenciális álláslehetőségről. Ehhez kapcsolódóan arra voltunk kíváncsiak, hogy a Nyíregyházi járás lakosai hogyan, milyen információs csatornán keresztül jutottak az éppen aktuális állásukhoz. Vizsgálatunk eredményei szerint a válaszadók meghatározó része (34\%) „közvetlenül a munkáltatóhoz fordult”, s jelezte elhelyezkedési szándékát. Valamivel kevesebben (27\%) nyilatkoztak úgy, hogy a legközvetlenebb környezet, a család, illetve a barátok útján eljutott információ segítségével jutottak jelenlegi állásukhoz. Álláshirdetésre jelentkezve 21\%-nak sikerült elhelyezkedni, $12 \%$ saját vállalkozásba kezdett, $\mathrm{s}$ a megkérdezettek $6 \%$-a az egyéb kategóriát jelölte meg. A járás településeit külön-külön vizsgálva a következőt tapasztaltuk: az átlagtól eltérően nagyobb mértékben számíthattak a családtagok és barátok segítségére a kótajiak (44,2\%), a napkoriak (31\%), a sényőiek (50\%) és a nyírturaiak (41,7\%). A saját vállalkozás elindítása pedig Nagycserkeszen és Nyírturán volt igazán meghatározó. Az említett települések családi vállalkozás keretében müködtetett zöldség- és gyümölcstermesztése köztudottan az egyik leginkább meghatározó megélhetési forrás.

\section{A foglalkoztatás nemenkénti eltérései}

A nemek szerinti foglalkoztatottsági arányában egyenlőtlenség figyelhető meg mind hazai, mind pedig európai uniós szinten. Nemenkénti összehasonlításban a korábbi évekhez hasonlóan a férfiak előnye rajzolódik ki. Magyarországon 2014-ben a férfiak foglalkoztatási rátája $60,5 \%$-volt, míg a nőké $48 \%$. (KSH. stadat 2.1.13.) Tehát a korábbi években is mérhetö, átlagosan 10\% körüli különbség állandósulni látszik, bár az is igaz, mind a nők, mind a férfiak relatív (saját csoportjához viszonyított) helyzete javult. 
3. sz. ábra: A hazai foglalkoztatási ráta alakulása nemenként (15-74 év), 1992-2014.

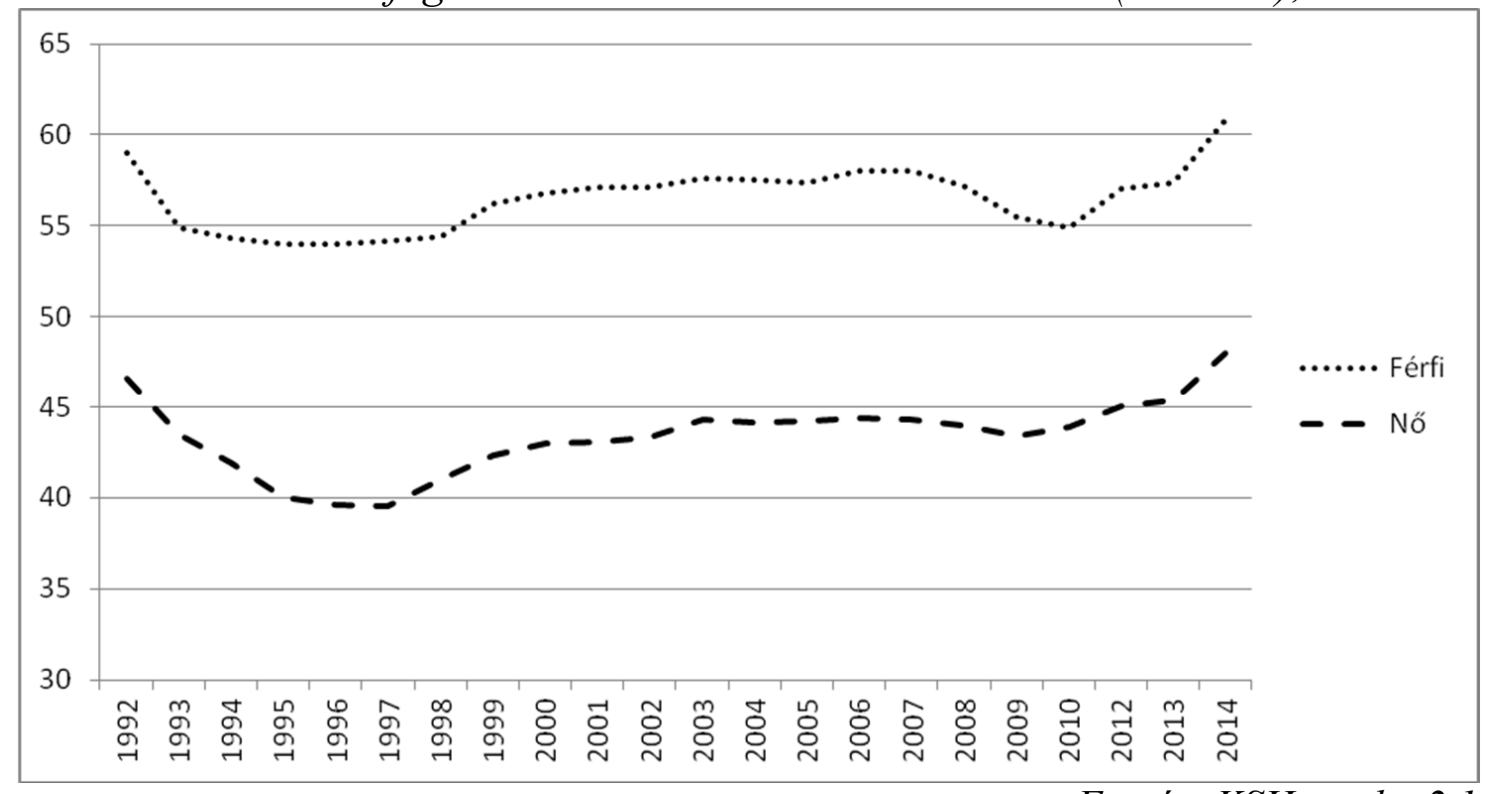

Forrás: KSH. stadat 2.1.13, https://www.ksh.hu/docs/hun/xstadat/xstadat_eves/i_qlf016.html

A Nyíregyházi járási vizsgálatban az „Ön Dolgozik-e jelenleg” kérdésre 1025 fő nő és 592 férfi válaszolt. A nők 45\%-a, míg a férfiak 63,5\%-a nyilatkozott úgy, hogy a megkérdezés idején dolgozott. Településenként vizsgálódva pedig azt tapasztaltuk, hogy a nyíregyházi nők 47\%-a, a férfiak 66\%-a válaszolt hasonlóan. (A járás további településein ez az arány átlagosan $43,6 \%$ és 61,3\%). A nyíregyházi nemenkénti foglalkoztatási megoszlást összevetve a panelvizsgálat megelőző három periódusával, a férfiak szempontjából túl nagy eltérést nem tapasztalunk, legalább is a 2012. évi adatokhoz viszonyítva. Azonban a nőknél meglepő visszaesés figyelhető meg, hiszen három évvel korábban még 54\% mondta azt, hogy dolgozott a megkérdezés pillanatában, vagyis a különbség három év távlatában 7\%-os. Az okok latolgatásánál két, talán három indok tünik logikusnak. Az egyik szerint vélhetően magasabb lett a gyermekgondozási szabadságon lévő nők mintán belüli aránya. A másik, hogy megnőtt a városi női munkanélküliség, a harmadik pedig, hogy vélhetően nagy számban éltek a nők a 40 éves munkaviszonnyal rendelkezőkre érvényes korkedvezményes nyugdíjazás lehetőségével. A következőkben erre a három okra fókuszálunk. A munkanélküliségi ráta emelkedése, mint felvetés, az adatok alapján megdőlni látszik. A 2015-ös adatfelvétel szerint a nyíregyházi válaszadó férfiak és nök közel azonos 5,2\%-a, illetve 5,9\%-a volt regisztrált munkanélküli a megkérdezés időpontjában. A gyermekvállalással összefüggő felvetésünket szintén el kell vetnünk, ugyanis 2012-ben a „, személyes okok miatt nem dolgozom” kategóriában a „GYES-en, GYED-en vagyok” válaszlehetőséget a válaszadó nők 20\%-a jelölte meg, míg 2015-ben ez az arány nem érte el a 10\%-ot sem, vagyis csökkent a gyermeknevelés, gyermekgondozás okán fizetett munkát nem végzők aránya. Némileg nőtt három év távlatában azoknak a nőknek az aránya, akik tanulmányok folytatása miatt nem jelentek meg a munka világában. (2012:1,5\%; 2015: 5,6\%) 
Okfejtésünkben a harmadik felvetésünk bizonyult magyarázó erejünek, mivel 2015-re jelentősen megugrott azon női válaszadók aránya, akik a személyes okokon belül a ,nyugdíjba akartam menni” kategóriát jelölték be (12\%-ról 66\%-ra). Az adatok ilyen mértékü átrendeződésében tehát egyértelmüen szerepet játszik a 40 év munkaviszonnyal rendelkező nőkre vonatkozó korkedvezményes nyugdíjazás lehetősége, mellyel 2011. év óta élhetnek az érintettek.

4. sz. ábra: A foglalkoztatottság aránya nemek szerint Nyíregyházán 2008, 2010, $2012(\%)$

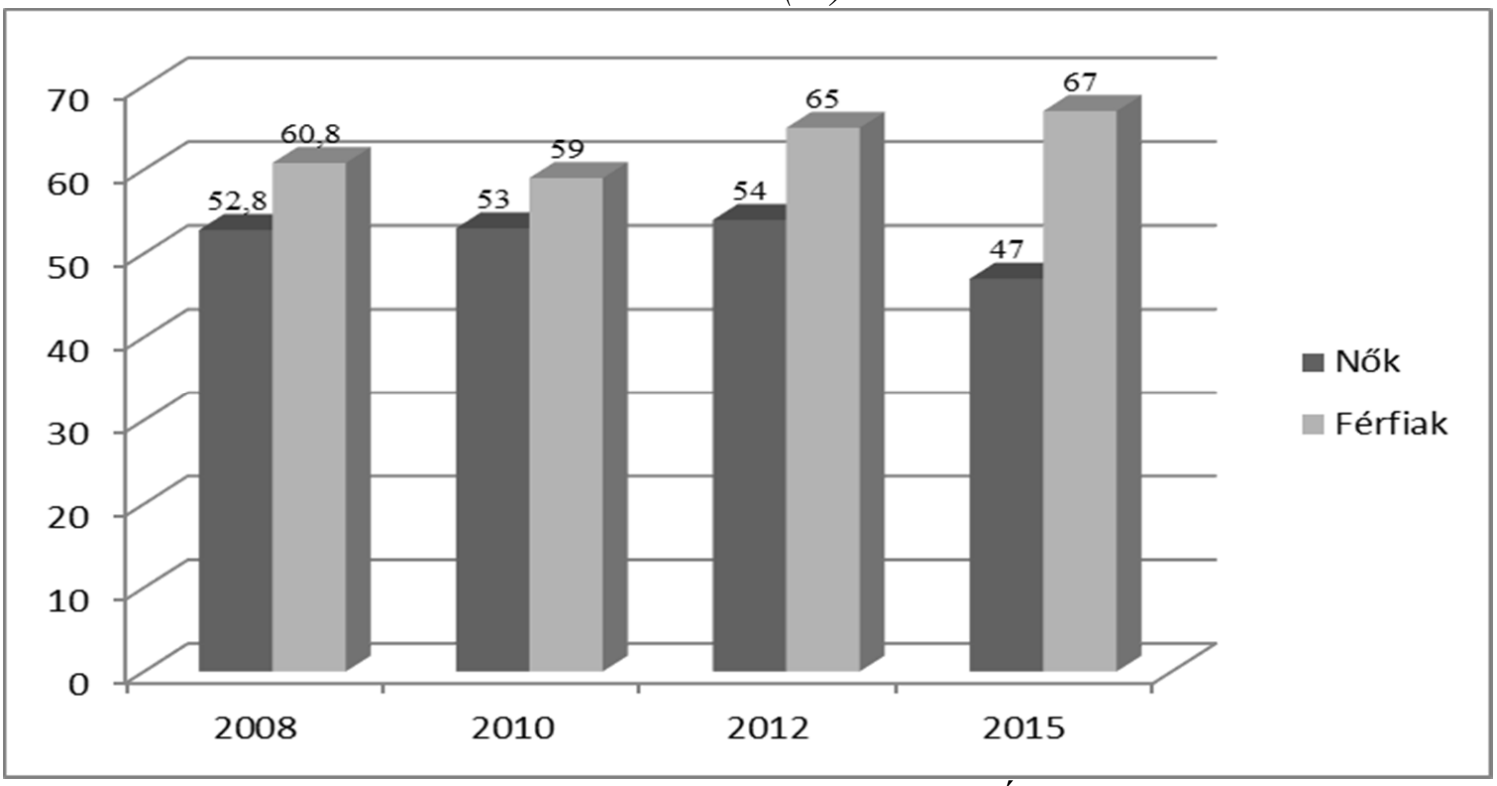

Forrás: Nyíregyháza Életminösége 2010, 2012, 2015.

5. sz. ábra: Foglalkoztatottsági arányok az iskolai végzettség függvényében, Nyíregyházán és a Nyíregyházi járásban (\%)

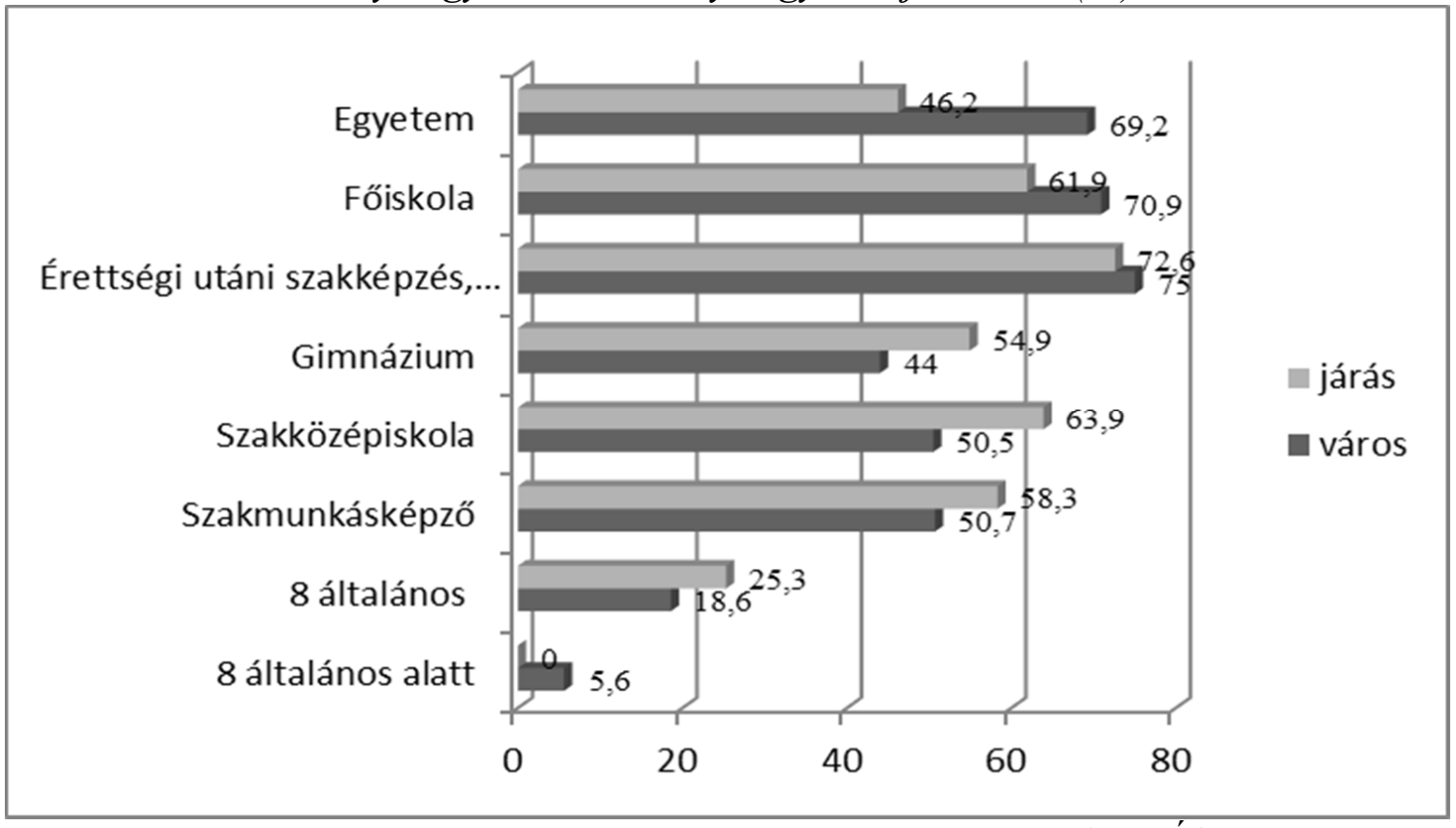

Forrás: Nyíregyháza Életminősége 2015. 
Az elhelyezkedési lehetőségeket nagymértékben meghatározza, befolyásolja az iskolai végzettség szintje. Mind a járási, mind a városi adataink egyértelmüen alátámasztják ezt az ok-okozati összefüggést. Az 5. számú ábrán jól látható, hogy a 8 általános iskolai végzettségnél magasabban kvalifikáltabb, középfokú végzettek, több mint kétszer annyian vannak foglalkoztatásban, a felsőfokú végzettség pedig ennél az aránynál is kedvezőbb képet mutat mind a város, mind a nyíregyházi járás tekintetében. Az adatok azt mutatják meg, hogy a megkérdezés pillanatában valaki foglalkoztatott volt-e vagy nem.

Ehhez hasonló a helyzetet mutatnak a KSH országos és régiós adatai ${ }^{18}$ a 6 . számú ábrán.

6. sz. ábra: Foglalkoztatottak száma, legmagasabb iskolai végzettség szerint 2014 (ezer fö)

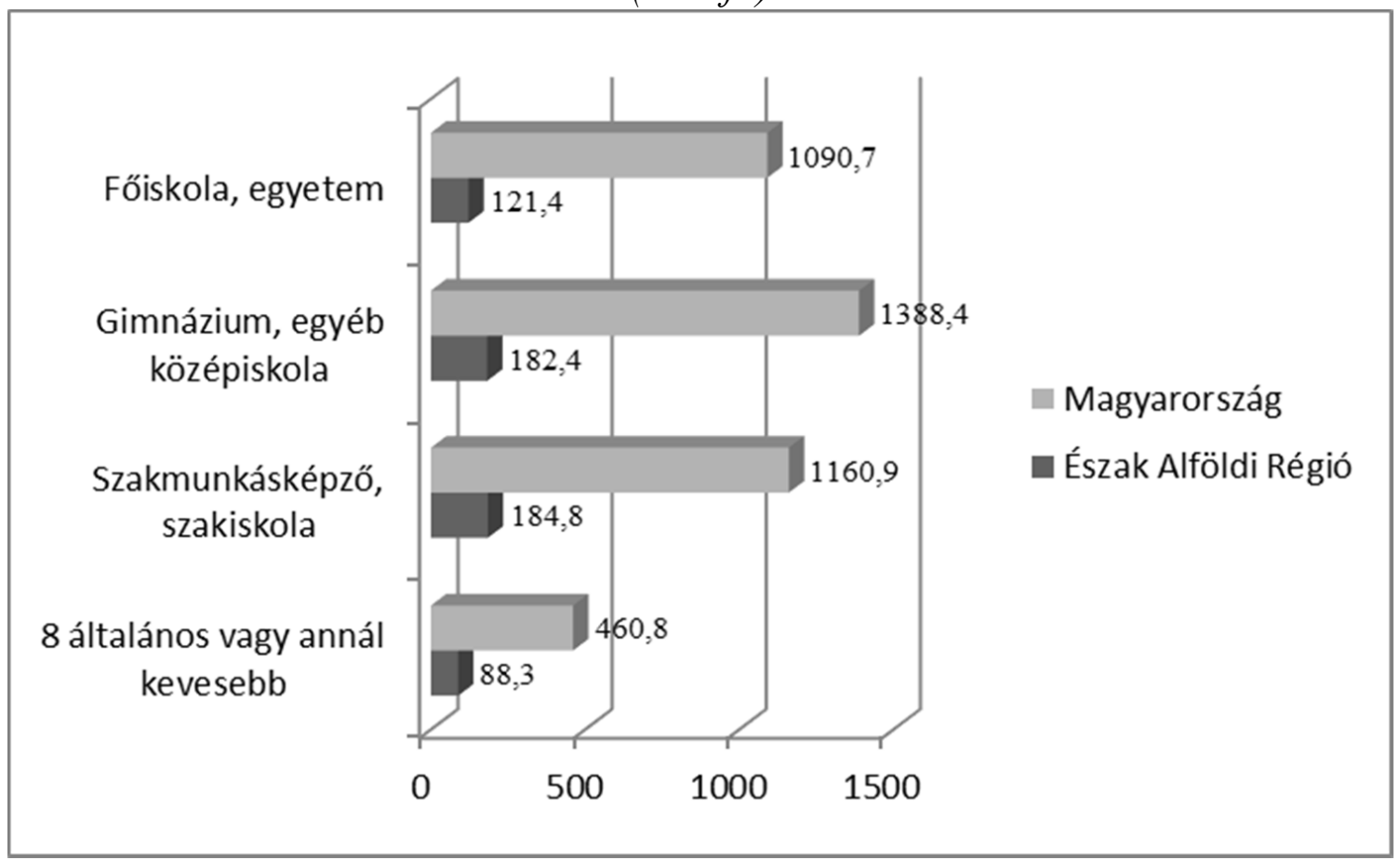

Forrás: KSH http://www.ksh.hu/stadat_eves_6_2

Ezen az ábrán is jól érzékelhető, hogy az ország és a régió adatai is azt mutatják, hogy jóval magasabb számban vannak azok a foglalkoztatottak, akiknek az alapfoknál magasabb iskolai végzettsége van. A KSH és a Háztartáspanel felvétel adatai szerint kissé kedvezőbb a foglalkoztatási arányszám az EUROSTAT adataihoz képest, illetve a legalább középfokú végzettségüek esetén a felsőfokú végzettséggel rendelkezőkkel szemben, amit feltételezhetően a nemzetközi és hazai adatgyüjtési módszer eltérése okoz. Az viszont mindkét adatsoron élesen kirajzolódik, hogy óriási a különbség az alapfokú végzettek és az ettől magasabb iskolai végzettséggel rendelkezők között. Még mindig a felsőfokú végzettség ad a

\footnotetext{
${ }^{18}$ A KSH és az EUROSTAT adatai közötti különbségeket az eltérő adatgyüjtési módszerek okozzák.
} 
legjobb elhelyezkedési lehetőséget az Észak-alföldi terület hátrányos helyzetétől függetlenül, legkevésbé az alacsony iskolai végzettséggel rendelkezők tudnak elhelyezkedni. Úgy is fogalmazhatunk, hogy az iskolai végzettség növekedésével csökken a munkanélküliség veszélye.

A legalacsonyabb iskolai végzettséggel rendelkezőknek a foglalkoztatottakon belüli súlya elenyésző, hasonlóan az országosan mért adatokhoz. Ez a megállapításunk nemzetközi összehasonlításban is megállja a helyét. A 7. és 8 . számú ábra szerint a 25-64 éves korosztály iskolai végzettség szerinti foglalkoztatási rátájában a felsőfokú végzettségüek egyértelmű előnye rajzolódik ki mind Magyarország, mind az Európai Unió Tagállamai vonatkozásában. Magyarország tekintetében annak ellenére, hogy a középfokú végzettséggel rendelkezők foglalkoztatási rátája évről évre növekvő tendenciát mutat, még mindig jóval elmaradnak az ettől magasabb iskolai végzettséggel rendelkezők foglalkoztatottságától. Az alacsony iskolai végzettség esetén figyelhető meg a legnagyobb bővülés a foglalkoztatás tekintetében, de még mindig óriási az adatok közötti rés. Hasonló összefüggések figyelhetők meg a közép- és felsőfok vonatkozásában.

7. sz. ábra: Foglalkoztatási ráta az iskolai végzettség függvényében Magyarország (25-64 évesek)

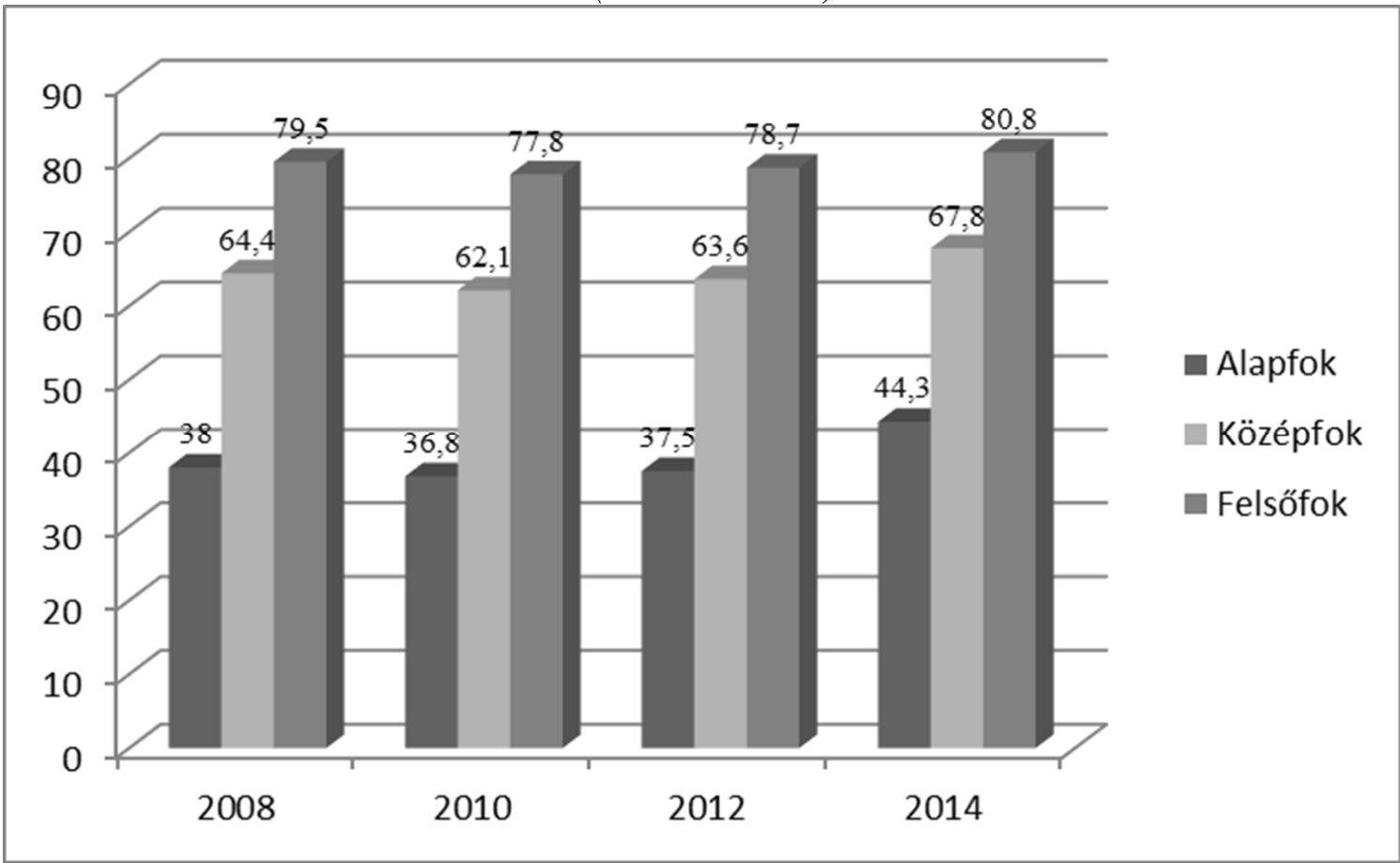

Forrás: Eurostat, http://ec.europa.eu/eurostat/tgm/refreshTableAction.do? tab $=$ table\&plugin $=1 \& p c o d e=t p s 0$ $0066 \&$ language $=$ en

Hasonló összefüggések figyelhetők meg a 7. számú ábrán az Európai Unió tagállamainak adatai között is. Itt is kiemelkedő a felsőfokú végzettek foglalkoztatási rátája, mind a középfokú végzettekhez, mind az alapfokú végzettekhez viszonyítva. 
Az adatok közötti rések mérsékeltebbek, mint a hazai adatok között, de itt is jelentősek az eltérések. A legnagyobb távolság az alapfokú végzettek és a felsőfokú végzettek között van. Az Unió vonatkozásában a felsőfokú végzettek és az alapfokú végzettek adatai közötti rés $18,3 \%$ pontnyi, míg ugyanez a hazai adatok között $23,5 \%$ pont.

8. sz. ábra: Foglalkoztatási ráta az iskolai végzettség függvényében EU $27^{19}$ (25-64 évesek)

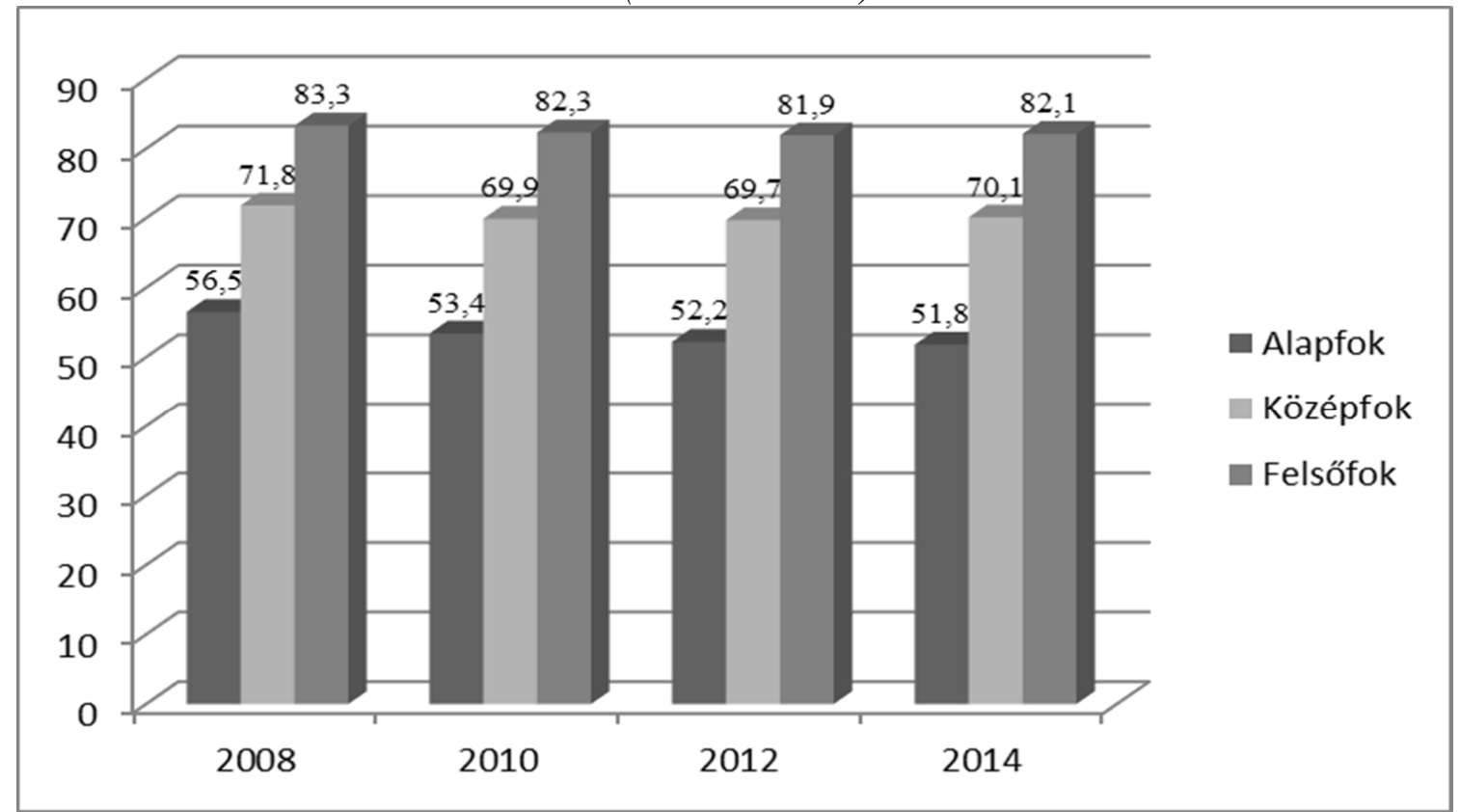

Forrás: Eurostat,

http://ec.europa.eu/eurostat/tgm/refreshTableAction.do?tab $=$ table $\&$ plugin $=1 \& p c o d e=t s d e$ c430\&language $=$ en

Összességében megállapítható, hogy a magas iskolai végzettséggel rendelkezők munkaerő-piaci helyzete az Európai Unióban és hazánkban is hasonlóan kedvezőnek tekinthető, az Unió előnye egyik évben sem számottevő. Az eltérések fokozódása középfokú szinten figyelhetőek meg, de hazánk jelentős felzárkózást mutatott 2014. évben ezen a területen. A kiemelkedően magas, $\mathrm{s}$ talán behozhatatlan tünő különbséget a legalacsonyabb iskolai végzettségü fokozatban tapasztalhatunk, itt a közösségi és hazai átlag közötti eltérés minden évben az unió javára billen.

\section{Munkanélküliség}

A munkanélküliséget vizsgálva az Európai Uniós, hazai, régiós, járási és városi tekintetben egyenes arányosság rajzolódik ki a foglalkoztatottsági adatokhoz képest. Elözőleg úgy fogalmaztunk, hogy az iskolai végzettség növekedésével csökken a munkanélküliség esélye. Ezen állításunkat valamennyi adatsor alátámasztja.

\footnotetext{
${ }^{19}$ 2013-tól Horvátország csatlakozásával EU 28-ra vonatkoznak az adatok.
} 
9. sz. ábra: Munkanélküliségi ráta az iskolai végzettség függvényében Magyarország (25-64 évesek)

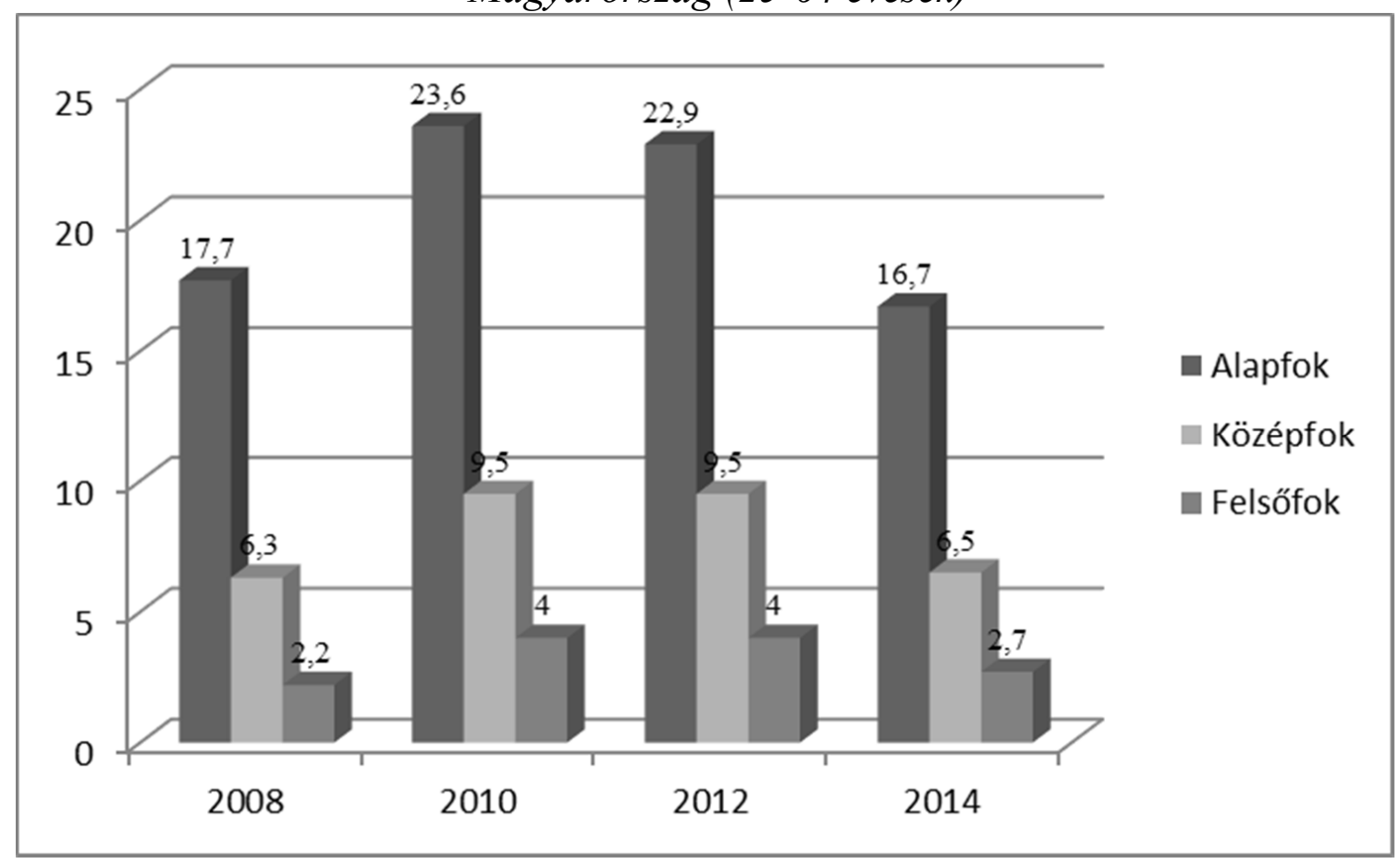

Forrás: Eurostat, http://ec.europa.eu/eurostat/tgm/refreshTableAction.do $?$ tab $=$ table \&plugin $=1 \&$ pcode $=$ tps00066\&language $=e n$

Hazánkban évről-évre megfigyelhető az a tendencia, hogy kiemelkedően magas az alapfokú iskolai végzettek munkanélküliségi rátája (9. számú ábra). Itt jóval magasabb az adatok közötti rés a legalacsonyabb iskolai végzettséggel rendelkezők és az ettől magasabban kvalifikáltabbak között. Annak ellenére, hogy a leginkább csökkenő tendencia éppen az alapfokú végzetteknél figyelhető meg, óriási a különbség ezen csoport és a másik két csoport között.

Hasonló helyzet tárul elénk az 10. számú ábrán az Európai Uniós Tagállamainak adatainál is. Itt is kiugróan magas az alapfokú végzettséggel rendelkezők munkanélküliségi rátája. Az adatok közötti legnagyobb rés az alapfokú végzettek és a felsőfokú végzettséggel rendelkezők között van. Hasonlóan a foglalkoztatási adatokhoz, az adatok közötti rések itt is az Európai Unió javára billennek a magyarországi adatokhoz képest. Az adatok azt mutatják, hogy Magyarországon az alapfokú végzettek adatai és a felsőfokú végzettek adatai között 14\% a különbség, az Unió tekintetében ugyanez a rés $11,7 \%$ a felsőfokú végzettek javára. Sokkal jelentősebb a különbség a középfokú végzettek és az alapfokú végzettek között, mint a középfokú végzettek és a felsőfokú végzettek között. 2014-ben az előbbi távolság az Unió tagállamainak adatai között 9,3\%, a hazai adatok 10,2\% különbséget mutatnak. Az utóbbi, tehát a középfokú végzettek és az alapfokú végzettek közötti különbség 2,4\% az unió adatai szerint és 3,8\% a hazai vonatkozásban. 
10. sz. ábra: Munkanélküliségi ráta az iskolai végzettség függvényében EU $27^{20}$

(25-64 évesek)

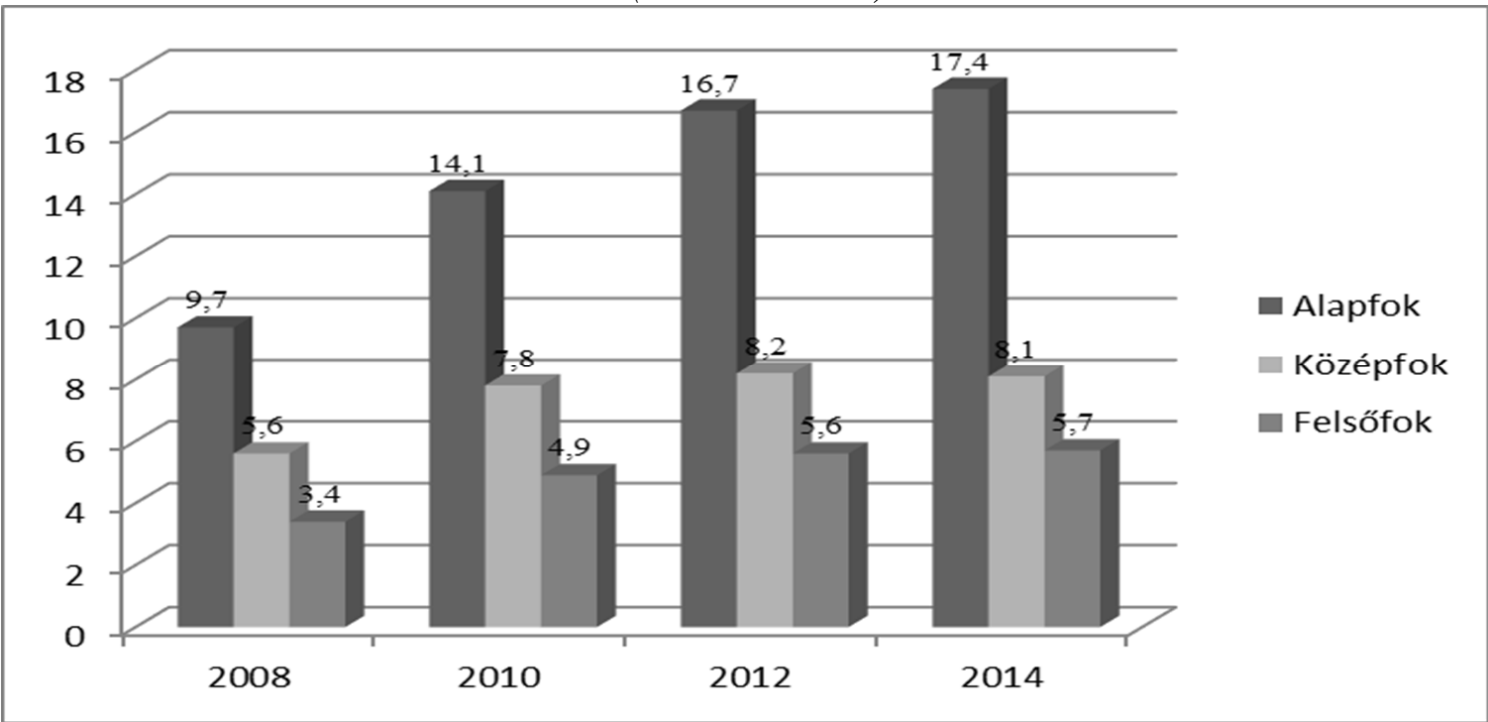

Forrás: Eurostat, http://ec.europa.eu/eurostat/tgm/refreshTableAction.do

?tab=table\&plugin $=1 \&$ pcode $=$ tps00066\&language $=$ en

Összhangban állnak ezzel a KSH és a Háztartás panel során felvett adatok is. A 11. számú ábra jól mutatja, hogy mind az Észak-alföldi régióban, mind Magyarországon a magasabb iskolai végzettség véd a munkanélküliséggel szemben. Az ország vonatkozásában jóval kisebb a távolság a három alacsonyabb iskolai végzettség között, mint ezeket a legmagasabb iskolai végzettséghez viszonyítjuk. Igaz ez az Észak-alföldi régió vonatkozásában is.

11. sz. ábra: Munkanélküliek száma, legmagasabb iskolai végzettség szerint 2014 (ezer fö)

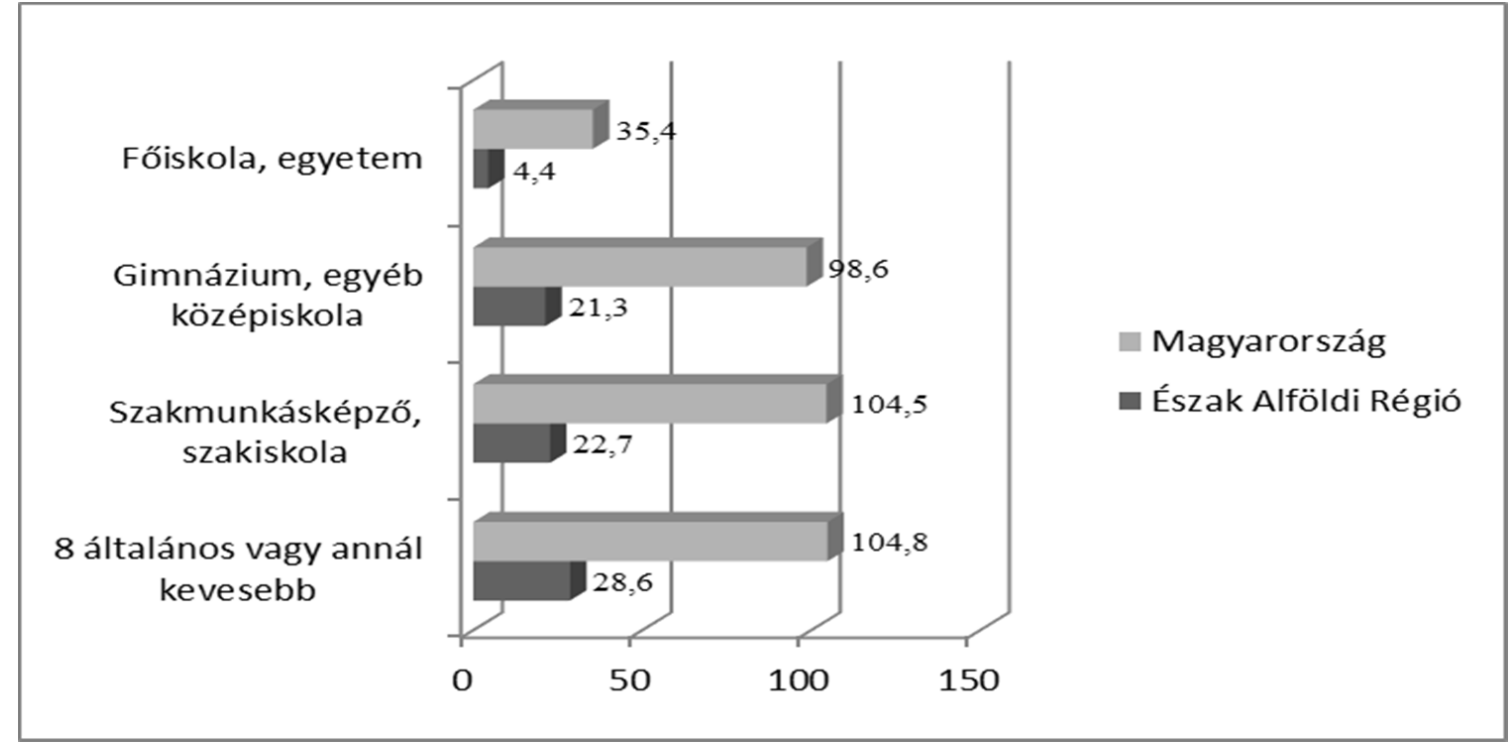

Forrás: KSH http://www.ksh.hu/stadat_eves_6_2

${ }^{20}$ 2013-tól Horvátország csatlakozásával EU 28-ra vonatkoznak az adatok. 
12. számú ábra: Munkanélküliségi arányok az iskolai végzettség függvényében, Nyíregyházán és a Nyíregyházi járásban (\%)

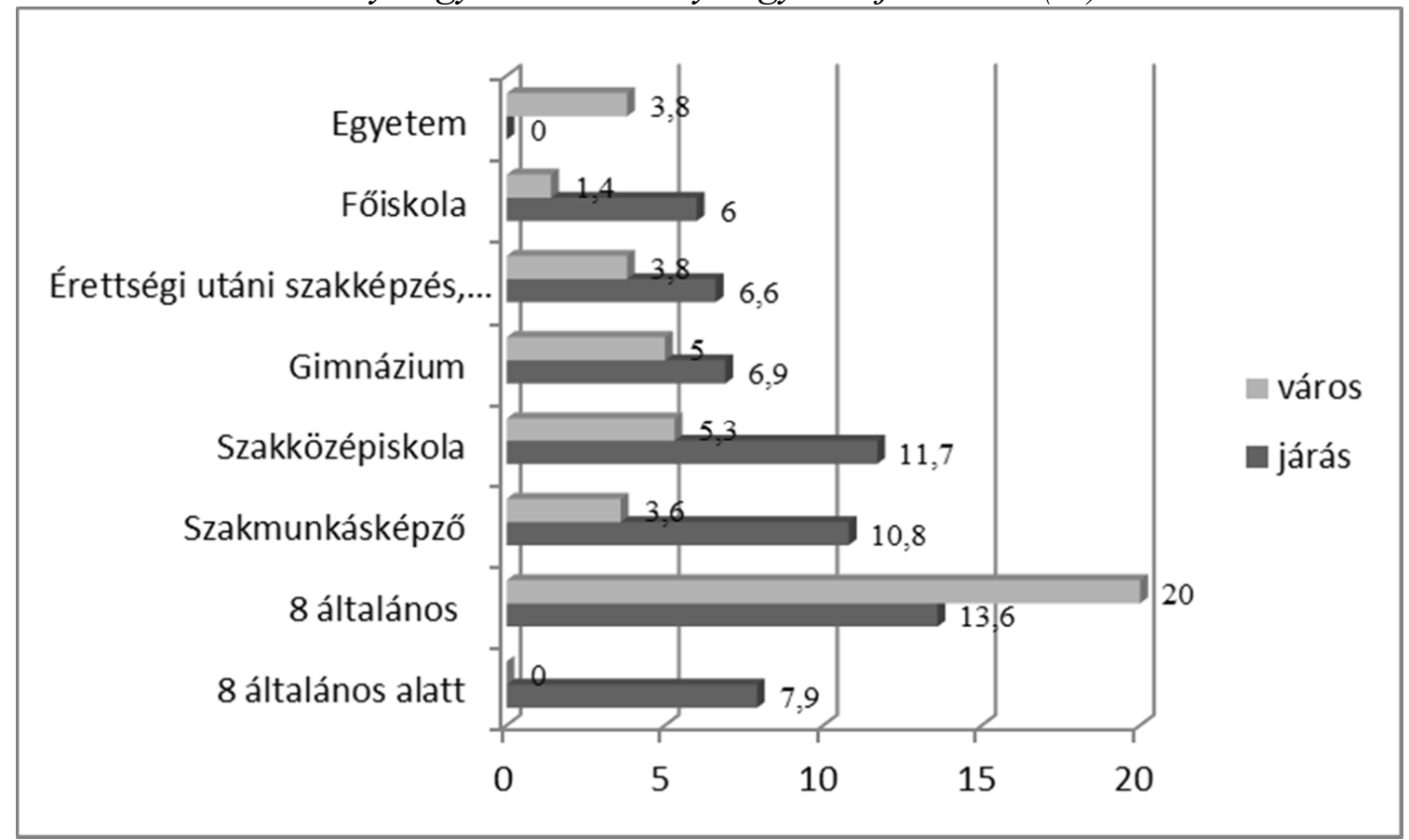

Forrás: Nyíregyháza Életminősége 2015.

A nyíregyházi és a Nyíregyházi járásokat vizsgálva megállapíthatjuk, annak ellenére, hogy a legkisebb különbséget a 8 általános iskolai végzettséggel, vagy az alatti végzettséggel rendelkezők között tapasztalhatunk, kimagaslóan magasak mindkét adatsor tekintetében a legalacsonyabban kvalifikáltak körében elöforduló arányok. Ezen adatsor is igazolja a magasabban kvalifikáltak előnyét a munkaerőpiacon. Minél magasabb az iskolai végzettség, annál kevésbé veszélyezteti az egyént a munkanélküliség. Ezeknél az adatsoroknál is megfigyelhetö, hogy az adatok közötti rések a legmagasabb és legalacsonyabb iskolai végzettséggel rendelkezők között van. A középfokú és alapfokú végzettséggel rendelkezők munkanélküliségi arányai között kissé mérsékeltebb az eltérés a város és a járás között, fokozódik az eltérés a magasabb iskolai végzettség esetén. A 12. számú ábrán az adatok azt mutatják meg, hogy a megkérdezés pillanatában a mintába kerültek regisztrált munkanélküliek-e vagy nem.

2014-ben Szabolcs-Szatmár-Bereg megyében átlagosan 45840 álláskereső volt nyilvántartva, mely 17,9\%-kal (9 991 fó) alacsonyabb az egy évvel korábbihoz képest. A legalacsonyabb iskolai végzettséggel rendelkezők, azaz a legfeljebb általános iskolát végzettek átlaglétszáma 23,2 ezer fő az álláskeresőkön belül 2014ben. Középfokú végzettséggel az álláskeresők 46,4\%-a (21 296 fö), míg felsőfokú végzettséggel 3,0\% (1 393) rendelkezett. Valamennyi kategóriában csökkent az álláskeresők száma 2013-hoz képest. Az alapfokú végzettséggel rendelkezők száma 16,9\%-kal (4 712 fó), a középfokon végzettek száma 18,6\%-kal (4 881 fö), a felsőfokú végzettséggel rendelkező álláskeresők száma pedig 22,2\%-kal (397 fö) csökkent. (Eures - Európai Foglalkoztatási Mobilitás) 
Ahogyan azt fentebb említettük, a megszerzett iskolai végzettség jelentősen meghatározza az elhelyezkedési lehetőségeket. Vizsgálatunk eredményei, hasonlóan az országos munkaerö-felmérés következtetéseihez, visszaigazolják a legmagasabb iskolai végzettség és a munkanélküliséggel érintettség közötti kapcsolatot. A munkanélküliséggel szembeni védettség egyenes aránnyal nő a megszerzett magasabb iskolai végzettséggel.

\section{Közfoglalkoztatás}

Magyarországon az elmúlt években központi szerepet játszik a foglalkoztatáspolitika eszköztárában a közfoglalkoztatás. A legelső közfoglalkoztatási program a 2009-ben elindult „Út a munkához program” volt, majd a 2010 után, 2011 év elején elindult „Új közfoglalkoztatási program” célja az volt, hogy a hátrányos helyzetü kistelepüléseken élö, alacsony iskolai végzettséggel rendelkezők egyrészt jövedelemhez juthassanak, másrészt a közfoglalkoztatás által kerüljenek visszavezetésre a nyílt munkaerőpiacra.

2011. január 1-jétől követően átalakult a közfoglalkoztatás. Megszünt a közmunkaprogram, a közhasznú munkavégzés és a közcélú munka. Ezeket egységesen a közfoglalkoztatás rendszer váltotta fel. A közfoglalkoztatásnak, mint a munkaviszony egy speciális formájának továbbra is célja, hogy a közfoglalkoztatásban részt vevő sikeresen kerüljön vissza, vagy be a munkaerőpiacra (2011. évi CVI. törvény a közfoglalkoztatásról és a közfoglalkoztatáshoz kapcsolódó, valamint egyéb törvények módosításáról).

Hazánkban 2013-ban már átlagosan 129,3 ezren vettek részt közfoglalkoztatásban. 2014-ben az oktatással kombinált speciális formával és a téli közfoglalkoztatással kiegészülve már 182,6 ezren vettek részt közfoglalkoztatásban. Ezeken a programokon jellemzően 6-8 hónapig vettek részt a közfoglalkoztatottak, így a részt vevők száma az átlagosnak közel kétszerese volt. A foglalkoztatottak mintegy 4\%-a sajátos körből került ki, ami jelentős hatással volt a foglalkoztatási trendre és a közfoglalkoztatottak összetétel jellemzőinek (például iskolai végzettség, lakóhely, munkanélküliség átlagos időtartama) alakulására is. Ekkor már jelentős számban voltak azok, akik így jutottak olyan rendszeres munkához, amire már évek óta esélyük sem volt. Leginkább a közfoglalkoztatás kiterjesztésével magyarázható a munkaerő piaci szempontból kedvezőtlen helyzetủ régiókban élő, legalacsonyabb iskolai végzettségüek foglalkoztatási mutatóinak javulása. (Munkaerö-piaci helyzetkép, 2014)

A közfoglalkoztatottak számának növekedése figyelhető meg járási és megyei szinten is a 13. számú ábrán. 
13. sz. ábra: A közfoglalkoztatottak számának alakulása Szabolcs-Szatmár-Bereg megyében és a Nyíregyházi járásban (fö)

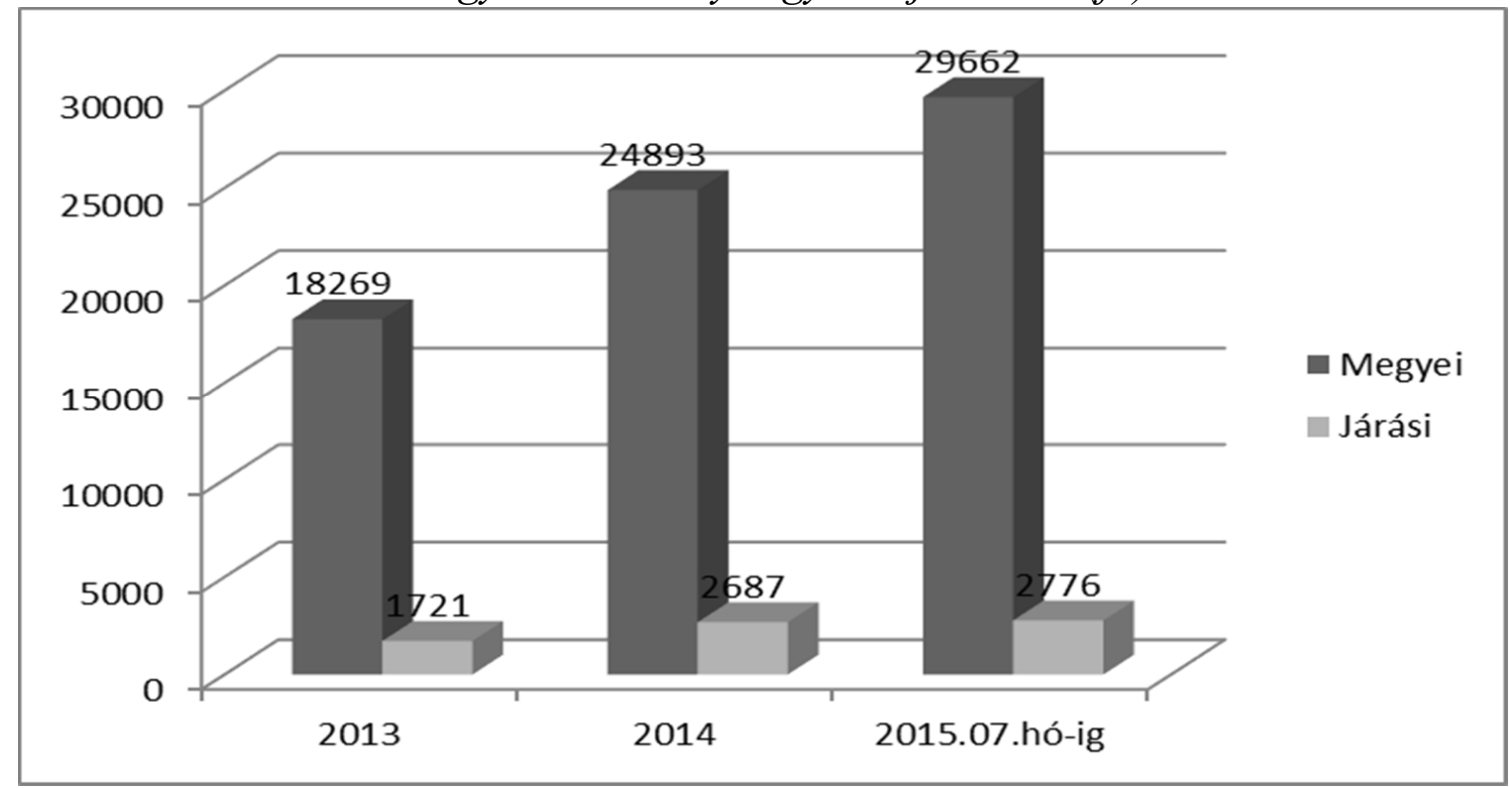

Forrás: http://kozfoglalkoztatas.bm.hu/

Az adatsoron jól látható, hogy mind a megyében, mind a járásban dinamikusan emelkedik a közfoglalkoztatásban résztvevők száma. Már 2014-ben is jelentősen növekedett a közfoglalkoztatásban részt vevők száma mindkét adatsoron, de még ennél is jelentős növekedés figyelhető meg 2015 első félévében.

14. számú ábra: A közfoglalkoztatottak átlagos számának alakulása a Nyíregyházi

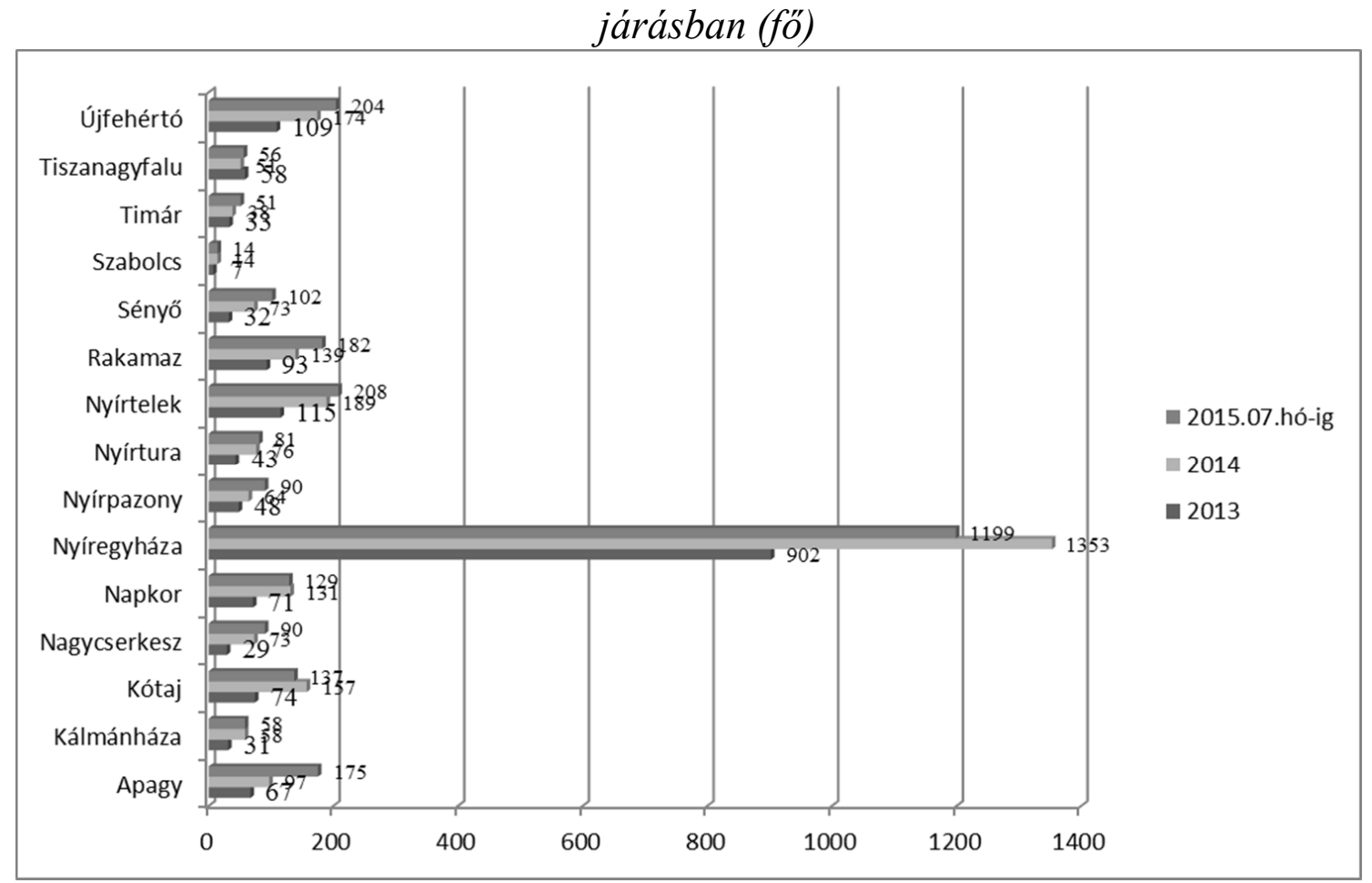

Forrás: http://kozfoglalkoztatas.bm.hu/ 
Ugyanez a tendencia mutatkozik, ha a Nyíregyházi járást településekre bontjuk le (14. számú ábra). Valamennyi település vonatkozásában igaz, hogy 2013-ról 2014. évre növekedett a közfoglalkoztatottak száma, és nagyobb számban további növekvő tendencia mutatkozik 2015. év első félévében is.

A Háztartáspanel vizsgálat lehetőséget ad a mintába bekerültek közfoglalkoztatás keretben történő foglalkoztatásának elemzésére is. Mivel ezt az adatot 2015-ben gyüjtöttük először, nincs módunk az előző évek adatainak összehasonlításával.

15. sz. ábra: Közfoglalkoztatásban részt vevök aránya (\%)

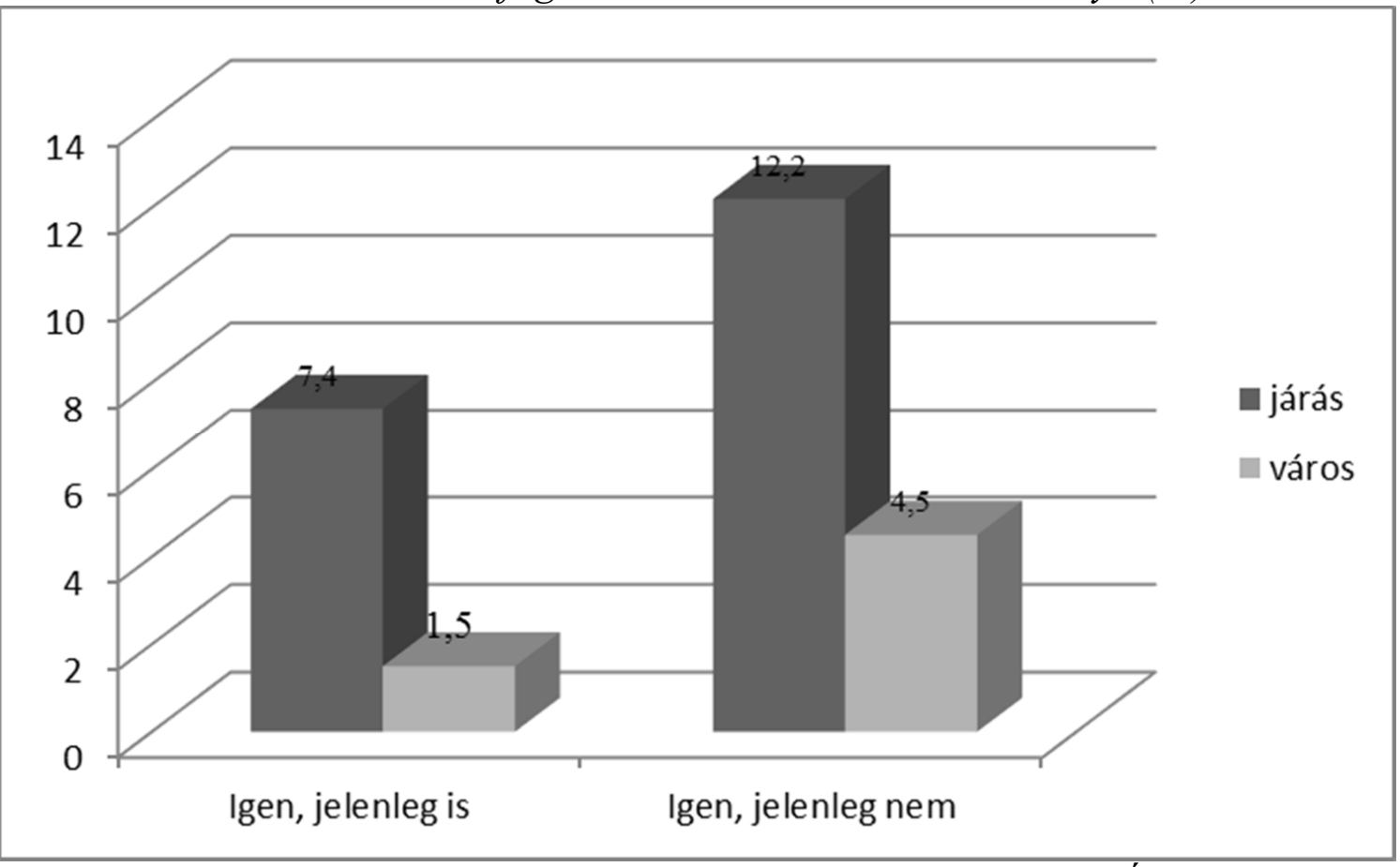

Forrás: Nyíregyháza Életminösége 2015.

A 15. számú ábrán a közfoglalkoztatásban való részvétel alakulását láthatjuk a mintába kerültek esetében városi és járási bontásban. Mind a város, mind a járás esetében jóval magasabb azok aránya, akik ugyan vettek már részt közfoglalkoztatásban, de jelenleg nem közfoglalkoztatottak. Ők lesznek azok, akik a megkérdezés pillanatában vagy elötte közfoglalkoztatási bérben részesültek. Ennek jelentőségét az adja, hogy a megélhetési költségekhez viszonyítva igen alacsony a közfoglalkoztatási bér összege, de annak nettó értéke még így is két és félszerese a foglalkoztatás helyettesítő támogatásnak.

A továbbiakban megvizsgáltuk a közfoglalkoztatásban résztvevők és valaha résztvevők iskolai végzettségének alakulását. Eredményeinket a 16. és 17. ábra mutatja. 
16. sz. ábra: A közfoglalkoztatásban jelenleg résztvevők iskolai végzettségének alakulása (\%)

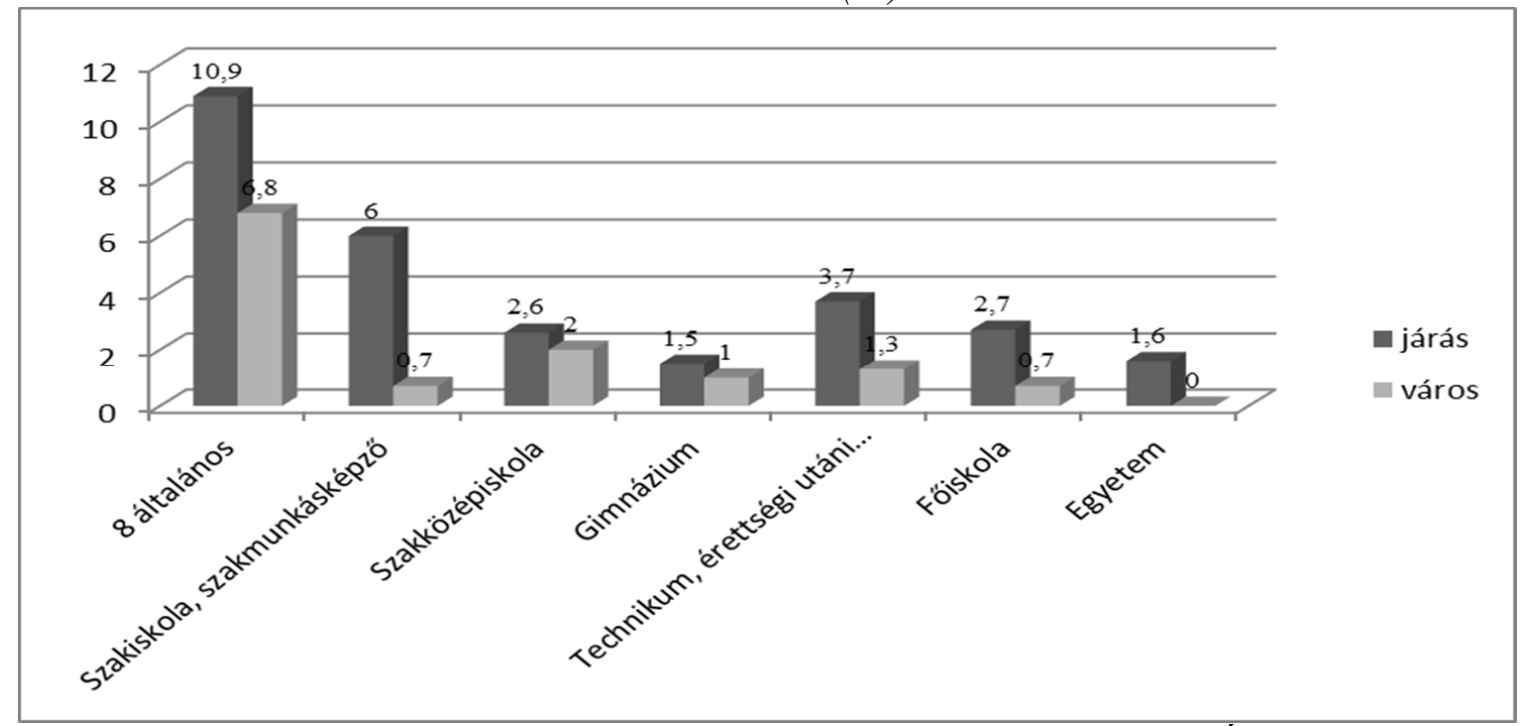

Forrás: Nyíregyháza Életminősége 2015.

Mindkét adatsoron az látható, hogy az iskolai végzettség és a közfoglalkoztatásban való részvétel között fordított arányosság áll fenn. Ez tehát azt jelenti, hogy valakinek minél magasabb iskolai végzettsége van, annál alacsonyabb arányban vesz részt a közfoglalkoztatásban. Mindez összhangban áll korábbi adatainkkal a foglalkoztatást és a munkanélküliséget illetően. Az alapfokú iskolai végzettséggel rendelkező munkanélküliek vannak legnagyobb arányban a közfoglalkoztatás keretében foglalkoztatva. Öket követik a középfokú iskolai végzettséggel rendelkezők. Legkisebb arányban azok a közfoglalkoztatottak vannak, akik felsőfokú végzettséggel rendelkeznek. A közfoglalkoztatási rendszer azon deklarált célja, hogy az alacsony iskolai végzettséggel rendelkezők jövedelemhez jussanak, megvalósult mind a járás, mind a város tekintetében.

17. sz. ábra: A közfoglalkoztatásban valaha résztvevők iskolai végzettségének alakulása (\%)

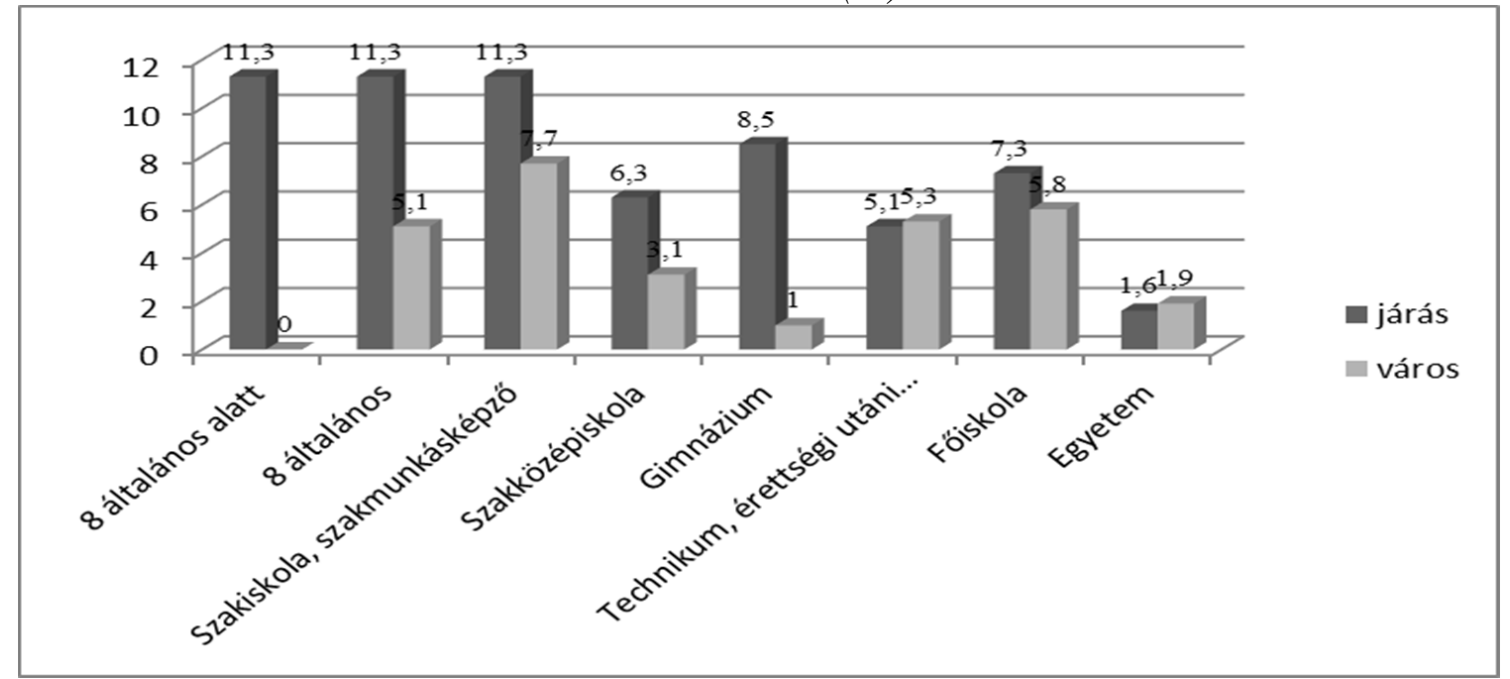

Forrás: Nyíregyháza Életminősége 2015. 


\section{Összefoglalás}

Elemző munkánkban Nyíregyháza város, valamint a Nyíregyházi járás lakóinak foglalkoztatási és munkanélküliségi jellemzőit vizsgáltuk. A városi helyzet elemzésében - hivatkozva a 2008-tól kétévenként ismétlődő kutatási előzményekre - lehetőségünk volt összehasonlítani a munkaerő-piaci jellemzőket, míg a járási adatok esetében inkább egyfajta helyzetképet adtunk a foglalkoztatás és munkanélküliség jellemzőiről. Munkánkban új vizsgálati dimenzióként beemeltük a foglalkoztatáspolitika egyik elemének, a közfoglalkoztatásnak az elemzését. Összességében megállapíthatjuk, hogy a nyíregyházi lakók foglalkoztatási színvonalában némi visszaesés tapasztalható, melynek okát - a rendelkezésre álló adatok alapján - a nők korábbihoz képest nagyobb arányú nyugdíjba vonulásával magyarázunk, melyet a jogszabályi változások tettek lehetővé. Eredményeink tehát inkább a válaszadók gazdasági aktivitási összetételében bekövetkezett változásokról árulkodnak. A foglalkoztatási és munkanélküliségi arányok vizsgálata Európai Uniós, országos, régiós, városi és járási szinten az iskolai végzettség függvényében egybecsengő eredményeket hoztak. Minden területre igaz, hogy a magasabb iskolai végzettség magasabb foglalkoztatási aránnyal és alacsonyabb munkanélküliségi aránnyal jár együtt. A közfoglalkoztatásra kiterjedt vizsgálatunk eredményei ezzel éppen fordított helyzetet mutatnak az országos tendenciákkal megegyezően. Minél magasabb az iskolai végzettség, annál alacsonyabb arányú a közfoglalkoztatásban való részvétel. A legalacsonyabb iskolai végzettséggel rendelkezők vesznek részt leginkább a közfoglalkoztatásban.

\section{Szerzők}

Rusinné Dr. Fedor Anita PhD. föiskolai docens

Balogh Erzsébet tanársegéd

\section{Felhasznált irodalom}

1.) Fábián Gergely - Takács Péter - Szigeti Fruzsina (2015): Jövedelmi helyzet és jövedelmi szegénység. Acta Med. Soc. Vol. 6. No. 18-19: 68-79

2.) Giddens, A. (1995): Szociológia. Osiris Kiadó. Budapest.

3.) Huszti Éva (2015): Mondd meg, kikkel töltöd az idődet, s megmondom, ki vagy. A társas támogatást nyújtó személyes kapcsolati háló néhány jellemzője és müködése a Nyíregyházi járásban. Acta Med. Soc. Vol. 6. No. 18-19: 121-144

4.) Jávorné Erdei Renáta - R. Fedor Anita - Berencsiné Madácsi Eszter (2014): A nyíregyházi lakosok önminősített egészségi állapota és annak változásai. Acta Med. Soc. 5. (12-13), 189-206.

6.) Jávorné Erdei Renáta - Gyulai Anikó - R. Fedor Anita - Takács Péter (2014): Quality of life and community activities. EURJSEA. 2 (1), 39-45.

7.) Malakucziné Póka Mária (2015): A Nyíregyházi járás települési szerkezeti, demográfiai, háztartási jellemzöi. Acta Med. Soc. Vol. 6. No. 18-19: 11-29

8.) R. Fedor Anita (2012): A gazdasági aktivitás lokális jellemzői. Nők és férfiak a „munka piacán”. In: Fábián Gergely - Patyán László - Huszti Éva (szerk.): Életminőség Nyíregyházán. Acta Medicinae et Sociologica folyóirat különszáma, Nyíregyháza, 83-98.

9.) R. Fedor Anita, Jávorné Erdei Renáta (2014): A foglalkoztatás jellemzői Nyíregyházán. Acta Med. Soc. 5. (12-13), 29-46.

10.) 2011. évi CVI. törvény a közfoglalkoztatásról és a közfoglalkoztatáshoz kapcsolódó, valamint egyéb törvények módosításáról. 


\section{Felhasznált statisztikai kiadványok}

1.) Eurostat, Statistics Explained Population and social conditions, Labour market http://appsso.eurostat.ec.europa.eu/nui/show.do Letöltve: 2015. október 02.

2.) Eurostat, Statistics Explained Population and social conditions, Labour market http://ec.europa.eu/eurostat/statistics-explained/index.php/Labour_market Letöltve: 2015. október 02.

1.) Eures - Európai Foglalkoztatási Mobilitás https://ec.europa.eu/eures/public/hu/homepage Letöltve: 2015. október 02 .

2.) KSH adatbázis http://statinfo.ksh.hu/Statinfo/haViewer.jsp Letöltve: 2015. október 02.

3.) KSH adatbázis http//www.ksh.hu/docs/hun/xstadat/xstadat_eves/i_qlf002.html Letöltve: 2015. október 03 .

4.) KSH stadat 6.2.1.10, https://www.ksh.hu/docs/hun/xstadat/xstadat_eves/i_qlf026b.html Letöltve: 2015. október 03.

5.) $\mathrm{KSH}$ stadat 6.2.1.11., https://www.ksh.hu/docs/hun/xstadat/xstadat_eves/i_qlf027b.html Letöltve: 2015. október 02.

6.) KSH. stadat 2.1.13., https://www.ksh.hu/docs/hun/xstadat/xstadat_eves/i_qlf016.html Letöltve: 2015. október 02 .

7.) Munkaerő - piaci helyzetkép, 2014. Statisztikai Tükör 2015/45. 2015. augusztus 24. 